\title{
Monograph
}

\section{Disentangling the diversity and taxonomy of Hymenophyllaceae (Hymenophyllales, Polypodiidae) in the Comoros}

\author{
Ahamada H. SAÏD ${ }^{1, *}$, Sabine HENNEQUIN ${ }^{2}$, \\ Germinal ROUHAN ${ }^{3}$ \& Jean-Yves DUBUISSON ${ }^{4}$ \\ ${ }^{1,3}$ Institut Systématique Evolution Biodiversité (ISYEB), Sorbonne Universités, \\ Muséum national d'Histoire naturelle, CNRS, UPMC, EPHE, Herbier National, \\ 57 rue Cuvier, CP39, 75005 Paris, France. \\ ${ }^{2,4}$ Institut Systématique Evolution Biodiversité (ISYEB), Sorbonne Universités, \\ UPMC Univ Paris 06, MNHN, CNRS, EPHE, \\ 57 rue Cuvier, CP48, 75005 Paris, France. \\ *Corresponding author: saidahamada.h@gmail.com \\ ${ }^{2}$ Email: sabine.hennequin@gmail.com \\ ${ }^{3}$ Email: rouhan@mnhn.fr \\ ${ }^{4}$ Email: dubuisson@mnhn.fr
}

\begin{abstract}
The inventory of biodiversity in the Comoros archipelago is still in progress. We propose here to contribute to this effort by assessing the diversity of the Hymenophyllaceae family, which forms one of the most diverse and emblematic fern communities in rainforests of the region. Data were extracted from floras, literature, recent collects and observations, and from an exhaustive investigation of the Paris herbarium collection. We also completed an online knowledge database including a computeraided identification (CAI) tool by using the Xper platform. Our checklist recognizes 21 taxa involving 1 endemic and 7 species newly reported for the archipelago. The taxonomy and discrimination of each taxon is discussed and a dichotomous key is provided. We also defined 80 morphological characters and their corresponding states into the Xper database and CAI that could be easily enriched for neighbouring areas and additional taxa.
\end{abstract}

Keywords. Comoros archipelago, ferns, Hymenophyllaceae, pteridophytes, western Indian Ocean, Xper.

Saïd A.H., Hennequin S., Rouhan G. \& Dubuisson J.-Y. 2017. Disentangling the diversity and taxonomy of Hymenophyllaceae (Hymenophyllales, Polypodiidae) in the Comoros. European Journal of Taxonomy 313: 1-53. https://doi.org/10.5852/ejt.2017.313

\section{Introduction}

The four islands of the Comoros (Mayotte or Maore, and belonging to the Union of Comoros: Ngazidja or Grande Comore, Ndzuani or Anjouan and Mwali or Mohéli), with all other islands of the southwestern Indian Ocean constitute one of the 25 world biodiversity hotspots (Myers et al. 2000; Labat et al. 2010). This theoretically results in an outstanding biodiversity for the archipelago according to its geographic location between Madagascar and East Africa (Fig. 1). However, the plant richness is still 
poorly known and consequently poorly managed and preserved. Literature on the archipelago remains fragmented, or only investigated and published for Mayotte (Pascal 2002; Barthelat \& Boullet 2005; Boullet 2011). A first checklist of plants was published by Voeltskow in 1917 including 935 taxa of vascular plants (172 species of 'pteridophytes' and 763 species of seed plants). The specific endemism rate was thus estimated at $15 \%$ for the whole flora, $6 \%$ for 'pteridophytes' and $18 \%$ for seed plants. Investigations of Adjanohoun et al. (1982) estimated the number of plant species in the Comoros to roughly 2000 including exotics. In Mayotte, 1243 species of vascular plants, of which $681(55 \%)$ are native (with 74 endemic to the Comoros), were recently reported (Barthelat \& Viscardi 2012), a count much higher than previously estimated for the whole archipelago. Given the size of Grande Comore, the largest island of the archipelago with $1148 \mathrm{~km}^{2}$, and existence on this island of environments and habitats absent in Mayotte $\left(375 \mathrm{~km}^{2}\right)$, the number of native vascular plants would certainly be closer to 1500 (Pascal 2002). Despite the increasing effort to estimate the current biodiversity on the archipelago, especially by the numerous field explorations conducted during the last 20 years mostly by the Muséum national d'Histoire naturelle (MNHN, Paris, France) in collaboration with the University of Comoros and the Centre national de Documentation et de Recherche scientifique (CNDRS, Moroni Comoros), the revision of the local flora is far from being achieved. We here propose to contribute to this knowledge effort by completing lists and taxonomic repository for ferns and lycophytes, and by focusing first on representative lineages that can form significant communities in local tropical forests: the Hymenophyllaceae (filmy ferns).

The 'pteridophyte' flora in the Comoros would include 130, 149 or 175 species according respectively to Roux (2009), the Flore de Madagascar et des Comores (Tardieu-Blot 1951-1971; Stefanovic et al. 1997)

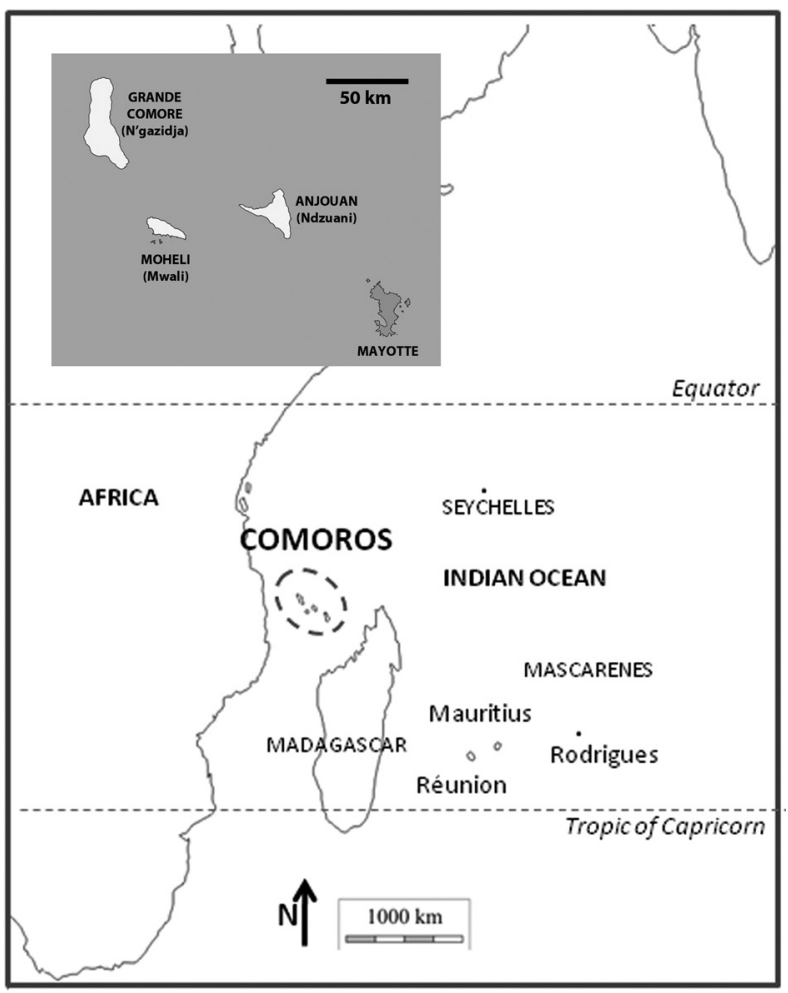

Fig. 1. Location of the Comoros archipelago in the western Indian Ocean; close-up on the four islands in grey inset; islands in white form the Union of Comoros, Mayotte in grey is a French overseas department. and Moulaert (1998). It is significantly lower than the Malagasy diversity with 35 families, 116 genera and at least 612 species (including $45 \%$ endemic; Roux 2009). But Madagascar is a large continental island of $592040 \mathrm{~km}^{2}$ while all four Comoros islands are from volcanic origin and do not exceed $2240 \mathrm{~km}^{2}$. Furthermore, Madagascar is from Gondwanan origin while Mayotte, the oldest island, is dated between 7.7 and 15 Myrs (Emerick \& Duncan 1982; Nougier et al. 1986). Comparatively, fern diversity in the archipelago remains thus quite high. In particular, Hymenophyllaceae or filmy ferns are one of the most diversified fern families in Comoros with 13 to 17 taxa (TardieuBlot 1951; Roux 2009). In addition, this family is often a key component of the understory epiphytic communities of lowland and highland rainforests (Dubuisson et al. 2003, 2013a).

Hymenophyllaceae indeed differ from all other ferns by, besides theirparticular sorus (developed later), an often translucent one-cell thick lamina without cuticle, explaining that such ferns are strongly restricted and representative to the wettest (and also threatened) habitats. Hymenophyllaceae traditionally comprised two genera: Hymenophyllum Sm. characterized 
by marginal bilabiate sori without developed base (Fig. 2A, F) and Trichomanes L. exhibiting marginal sori with a developed tubular base (Fig. 2B). The most recent revision (Ebihara et al. 2006), based on molecular and morphological evidence, recognizes nine distinct monophyletic genera. The genus Hymenophyllum more or less covers the original genus while Trichomanes is now divided into eight distinct genera (Abrodictyum C.Presl, Callistopteris Copel., Cephalomanes C.Presl, Crepidomanes (C.Presl) C.Presl, Didymoglossum Desv., Polyphlebium Copel., Trichomanes, and Vandenboschia Copel.) which together form the trichomanoids as sister clade of Hymenophyllum or hymenophylloids. All these genera, except Cephalomanes and Callistopteris, are present in the western Indian Ocean and potentially in Comoros. However, recent taxonomic studies in the Indian Ocean (Pynee et al. 2012; Dubuisson et al. 2013b, 2014, 2016; Bauret et al. 2015) show that the family still needs additional taxonomic investigations, with potential new taxa for the region. Consequently, the diversity of Hymenophyllaceae in Comoros also needs a revision that can take advantage of recent taxonomic studies (as reported hereabove), recent collects (mostly by F. Rakotondrainibe, M. Pignal and G. Rouhan, MNHN, Paris) and exhaustive investigations of herbarium collections. This paper proposes therefore to: 1) evaluate the diversity of Hymenophyllaceae in Comoros with the associated and updated taxonomic revision; and 2) provide with taxonomic tools via identification keys and an online knowledge database on Comorian Hymenophyllaceae in the context of biological inventories.

\section{Material and methods}

The establishment of a complete checklist of Hymenophyllaceae in Comoros was conducted by combining two complementary approaches: 1) consultation of floras and available databases; 2) investigation of herbarium materials corresponding to specimens of Comoros kept at $\mathrm{P}$.

\section{Floras and databases}

Data were first extracted from floras and checklists that include information on ferns in the western Indian Ocean and neighbouring areas: Kuhn (1868); Baker (1877); Cordemoy (1895); Sim (1915); Bonaparte (1920a, 1920b, 1923, 1925); Christensen (1920); Tardieu-Blot (1951, 1960, 1977, 2008); Schelpe (1966); Lorence (1978); Schelpe \& Anthony (1986); Burrows (1990); Kornaś (1993, 1994); Beentje (2008); Roux (2009) and Grangaud (2010). They were then confronted to online databases: Sonnerat (MNHN, Paris herbarium P, https://science.mnhn.fr/institution/mnhn/collection/p/item/search/ form), the Checklist of ferns and lycophytes of the world (http://worldplants.webarchiv.kit.edu/ferns/), the Index of the vascular flora of La Réunion (http://flore.cbnm.org), and Mayotte (http://floremaore. cbnm.org), The Plant List (http://www.theplantlist.org) and the Catalogue of the Vascular Plants of Madagascar included in Tropicos (http://www.tropicos.org/Project/MADA). The crossed data obtained from floras and databases were then updated according to recent taxonomy. This update was carried out via IPNI (http://www.ipni.org), Tropicos (http://www.tropicos.org), Roux (2009), Grangaud (2010) and especially by following the recent phylogenetic studies (Ebihara et al. 2006; Pynee et al. 2012; Dubuisson et al. 2013b, 2014, 2016; Bauret et al. 2015). The aim of these taxonomic and nomenclatural investigations was to check and to obtain, for every potential distinct species, a scientific valid and updated name. Last access for all the online databases was done in August 2016.

\section{Herbarium specimens}

The P herbarium (herbarium acronym following Thiers 2016) historically hosts one of the richest collections of specimens from the western Indian Ocean, mostly collected from the $19^{\text {th }}$ century and regularly enriched by recent field prospection. Using a binocular microscope, we conducted an exhaustive morphological study of the 156 Hymenophyllaceae specimens collected in the Comoros and kept at P. Morphological observations were compared with the descriptions from literature, especially the floras cited above in addition to original descriptions for some species (Poiret 1808; Willdenow 1810; Schrader 1818; Desvaux 1827; Hooker \& Greville 1831; Presl 1843; van den Bosch 1858, 1861; 

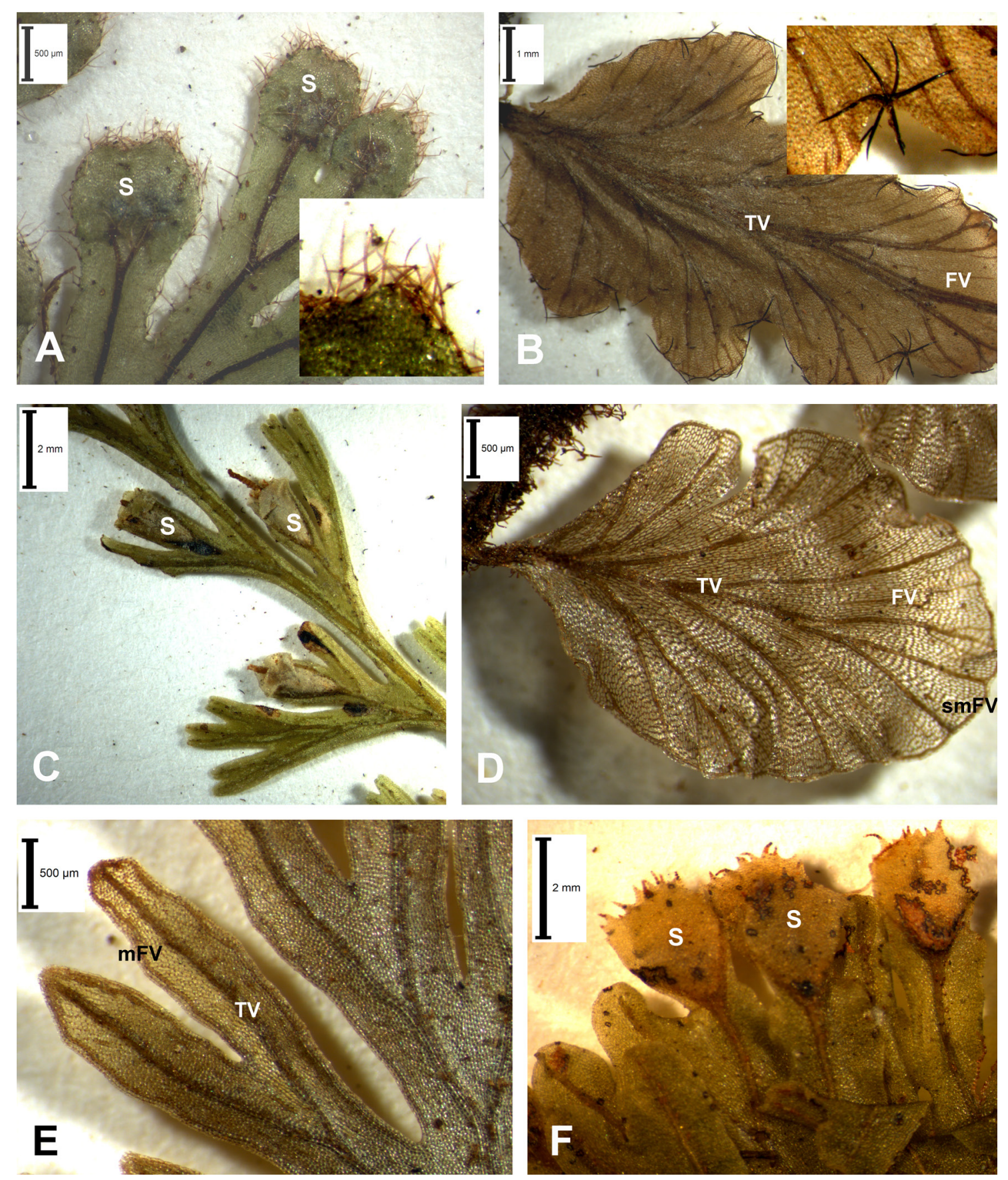

Fig. 2. Illustration of representative descriptors and states used in the Xper database (see Appendix 1). A. Hymenophyllum hirsutum (L.) Sw., typical bilabiate sori (S) without a developed base, fully hairy lamina with pedunculated brown trichomes (see inset). B. Didymoglossum robinsonii (Hook. ex Baker) Copel., false veins (FV) parallel but not connected to true veins (TV) and marginal dark trichomes clustered here by 6 (see inset). C. Crepidomanes inopinatum (Pic.Serm.) J.P.Roux, typical trichomanoid sori (S) with a developed tubular base, lips are here dilated as a collar. D. Didymoglossum rotundifolium (Bonap.) J.P.Roux, false veins (FV) parallel but not connected to true veins (TV) and continuous submarginal false vein (smFV), here the one-cell thick lamina appears well translucent. E. Crepidomanes bipunctatum (Poir.) Copel., false veins more or less continuous and parallel to margins (mFV) and not connected to true veins (TV). F. Hymenophyllum sibthorpioides (Bory ex Willd.) Mett. ex Kuhn, bilabiate sori (S) with toothed margins. Photographs by A.H. Saïd. 
Baker 1877; Bonaparte 1920a, 1920b; Christensen 1920; Pichi Sermolli 1983). Type specimens for 14 taxa (located at P) and other specimens from Madagascar (115), La Réunion (65), Mauritius (64), Seychelles (26) and continental Africa (32) including additional taxa a priori absent in Comoros were also examined for comparison, for a total of 458 sheets. This morphological study allowed identifying and discriminating morpho-taxa present in the archipelago and providing updated descriptions to be integrated into the knowledge database (see hereafter) and for the identification keys.

Distributions of taxa within the Comoros archipelago were given based on herbarium specimens examined.

\section{Knowledge database and identification tools using Xper2 and Xper3}

Dichotomous keys are the traditional tool used to make taxon identification. But more powerful tools exist since the development of softwares dedicated to taxonomic description and Identification Assisted by Computer (CAI). This is the case of Xper2 (Ung et al. 2010) and its updated Xper3 version (http://www. xper3.fr/?language $=$ en) that we used in this study. Xper2 is a classical software usable only offline while Xper3 is the online collaborative version. Xper platforms propose automatic edition of identification keys. Compared to a traditional dichotomous key where the path is imposed and identification can be difficult or impossible if the selected characters are lacking or not well observable, Xper users can select any character. Furthermore, inapplicability or dependencies (i.e., the absence of a descriptor does not allow the presence of some others and inversely) and uncertainty are taken into account and users can integrate continuous/quantitative data (e.g., accurate leaf length). The tools are therefore more flexible and interactive. However, the construction of the knowledge database that allows the identification also requires that a list of appropriate descriptors (characters) and states was carefully defined, completed and coded for every taxon. These descriptors and states were extracted from previous studies (Dubuisson 1997; Hennequin 2003; Pynee et al. 2012; Dubuisson et al. 2013b, 2014; Bauret et al. 2015) and from present morphological investigations, and more especially adapted to the Comorian taxa and specimens.

\section{Results}

Investigations of floras, databases and collections allowed us to recognise for the Comoros 21 species of Hymenophyllaceae belonging to seven genera to be compared to previous studies recognising respectively 13 and 17 species. These three checklists are compared in Table 1 . The most diversified genera in the archipelago are Didymoglossum (7 spp.) including the single Comorian endemic species D. kirkii (Hook.) Ebihara \& Dubuisson, Hymenophyllum (6 spp.) and Crepidomanes (4 spp.). Abrodictyum, Polyphlebium (newly reported for the archipelago), Trichomanes and Vandenboschia are each represented by a single species. Diversity of the overall morphology is illustrated by representative species as observed in situ (Fig. 3).

\section{Distribution of Hymenophyllaceae in Comoros and collect effort (Table 2)}

According to the 156 specimens studied, the richest island for Hymenophyllaceae diversity is Anjouan with 16 out of the $21(76.2 \%)$ species reported for the archipelago. Grande Comore is less diversified with 13 species $(61.9 \%)$. The lowest diversified islands are Mayotte and the smallest one, Mohéli, with 11 taxa each (52.4\%). In addition, the species are not uniformly distributed. For example, Grande Comore hosts six out of six (100\%) species of Hymenophyllum and one out of seven (14.3\%) species of Didymoglossum while Mayotte hosts one out of six (16.7\%) species of Hymenophyllum and six out of seven $(85.7 \%)$ species of Didymoglossum. While Grande Comore and Mayotte have benefited from recent field trips and Anjouan from many old collects ( $19^{\text {th }}$ and $20^{\text {th }}$ centuries), Mohéli remained quite little explored before the recent field trips organized in the archipelago since 2008. Before 2008, only three species were actually reported in Mohéli and recent investigations allowed the identification of at least seven additional taxa. Before 2008 and the recent collects in the archipelago, Anjouan has provided 
Table 1. List of Hymenophyllaceae species recorded for the Comoros archipelago and comparison with previous studies; all species in Tardieu-Blot (1951) were reported by her as belonging to Trichomanes or Hymenophyllum, following the traditional bi-generic classification of Hymenophyllaceae.

(*) Synonym of Hymenophyllum tenellum (Jacq.) Kuhn, but most specimens in collection identified as $H$. fumarioides Bory ex Willd. would be in fact $H$. capense Schrad. (as discussed on p. 26). X = present or reported present.

\begin{tabular}{|c|c|c|c|}
\hline Taxa & $\begin{array}{c}\text { Present } \\
\text { study }\end{array}$ & Tardieu-Blot (1951) & Roux (2009) \\
\hline $\begin{array}{l}\text { Abrodictyum pseudorigidum } \\
\text { Bauret \& Dubuisson }\end{array}$ & $\mathrm{X}$ & & $\begin{array}{l}\mathrm{X} \text { (as Abrodictyum rigidum } \\
\text { (Sw.) Ebihara \& Dubuisson) }\end{array}$ \\
\hline $\begin{array}{l}\text { Crepidomanes bipunctatum } \\
\text { (Poir.) Copel. }\end{array}$ & $\mathrm{X}$ & $\mathrm{X}$ & $\mathrm{X}$ \\
\hline $\begin{array}{l}\text { Crepidomanes inopinatum } \\
\text { (Pic.Serm.) J.P.Roux }\end{array}$ & $\mathrm{X}$ & & \\
\hline $\begin{array}{l}\text { Crepidomanes minutum } \\
\text { (Blume) K.Iwats. var. mascarenensis } \\
\text { Pynee \& Dubuisson }\end{array}$ & $\mathrm{X}$ & $\begin{array}{c}\text { X (as Trichomanes mannii } \\
\text { Hook.) }\end{array}$ & $\mathrm{X}$ (as C. mannii (Hook.) J.P.Roux) \\
\hline $\begin{array}{l}\text { Crepidomanes trinerve } \\
\text { (Baker) Dubuisson \& Ebihara }\end{array}$ & $X$ & & \\
\hline $\begin{array}{l}\text { Didymoglossum cuspidatum } \\
\text { (Willd.) Ebihara \& Dubuisson }\end{array}$ & & $\begin{array}{l}\text { X (restricted to one out of } \\
\text { the two recognized varieties } \\
\text { Trichomanes cuspidatum } \\
\text { Willd. var. densestriatum } \\
\text { C.Chr.) }\end{array}$ & $\begin{array}{l}\mathrm{X} \text { (restricted to one out of the two recognized } \\
\text { varieties } T . \text { cuspidatum var. densestriatum) }\end{array}$ \\
\hline $\begin{array}{l}\text { Didymoglossum erosum } \\
\text { (Willd.) J.P.Roux }\end{array}$ & $\mathrm{X}$ & & $\begin{array}{l}\mathrm{X} \text { (although 'Comoros' is missing in the } \\
\text { distribution, it is recognized through the } \\
\text { synonym Trichomanes erosum Willd. var. } \\
\text { laciniatum Mett. ex Peter for which the type is } \\
\text { from the Comoros) }\end{array}$ \\
\hline $\begin{array}{l}\text { Didymoglossum hildebrandtii } \\
\text { (Kuhn) Ebihara \& Dubuisson }\end{array}$ & $\mathrm{X}$ & $\mathrm{X}$ & $\mathrm{X}$ \\
\hline $\begin{array}{l}\text { Didymoglossum kirkii } \\
\text { (Hook.) Ebihara \& Dubuisson }\end{array}$ & $\mathrm{X}$ & $\mathrm{X}$ & $\mathrm{X}$ \\
\hline $\begin{array}{l}\text { Didymoglossum lenormandii } \\
\text { (Bosch) Ebihara \& Dubuisson }\end{array}$ & $\mathrm{X}$ & $\mathrm{X}$ & $\mathrm{X}$ \\
\hline $\begin{array}{l}\text { Didymoglossum lorencei } \\
\text { (Tardieu) Ebihara \& Dubuisson }\end{array}$ & $X$ & & \\
\hline $\begin{array}{l}\text { Didymoglossum robinsonii } \\
\text { (Hook. ex Baker) Copel. }\end{array}$ & $\mathrm{X}$ & & \\
\hline $\begin{array}{l}\text { Didymoglossum rotundifolium } \\
\text { (Bonap.) J.P.Roux }\end{array}$ & $\mathrm{X}$ & $\mathrm{X}$ & $\mathrm{X}$ \\
\hline Hymenophyllum capense Schrad. & $\mathrm{X}$ & & $\mathrm{X}$ \\
\hline Hymenophyllum capillare Desv. & $\mathrm{X}$ & & $\mathrm{X}$ \\
\hline $\begin{array}{l}\text { Hymenophyllum fumarioides } \\
\text { Bory ex Willd. }(*)\end{array}$ & & $X$ & \\
\hline Hymenophyllum hirsutum (L.) Sw. & $\mathrm{X}$ & X (as H. ciliatum (Sw.) Sw.) & $\mathrm{X}$ \\
\hline $\begin{array}{l}\text { Hymenophyllum inaequale } \\
\text { (Poir.) Desv. }\end{array}$ & $\mathrm{X}$ & $X$ & $X$ \\
\hline Hymenophyllum kuhnii C.Chr. & $\mathrm{X}$ & & \\
\hline $\begin{array}{l}\text { Hymenophyllum sibthorpioides } \\
\text { (Bory ex Willd.) Mett. ex Kuhn }\end{array}$ & $\mathrm{X}$ & $\mathrm{X}$ & $\mathrm{X}$ \\
\hline $\begin{array}{l}\text { Polyphlebium borbonicum } \\
\text { (Bosch) Ebihara \& Dubuisson }\end{array}$ & $\mathrm{X}$ & & \\
\hline Trichomanes boivinii Bosch & $\mathrm{X}$ & & \\
\hline Trichomanes cupressoides Desv. & & $\mathrm{X}$ & $\mathrm{X}$ \\
\hline $\begin{array}{l}\text { Vandenboschia gigantea } \\
\text { (Bory ex Willd.) Pic.Serm. }\end{array}$ & $\mathrm{X}$ & $\mathrm{X}$ & $\mathrm{X}$ \\
\hline Vandenboschia radicans (Sw.) Copel. & & & $\mathrm{X}$ \\
\hline
\end{tabular}



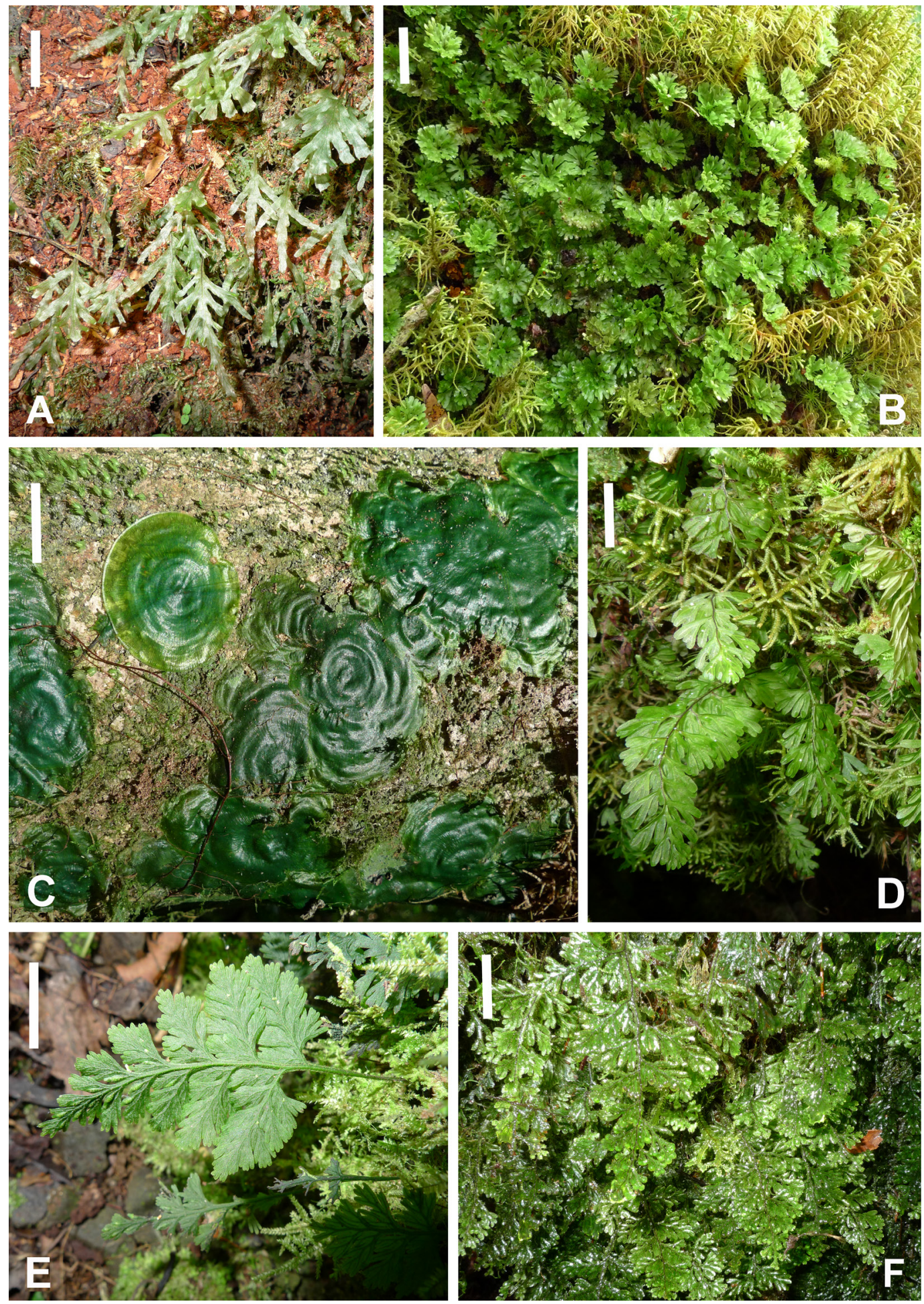

Fig. 3. Representative Comorian Hymenophyllaceae as observed in situ in rainforests (here from Grande Comore or Mohéli). A. Endemic Didymoglossum kirkii (Hook.) Ebihara \& Dubuisson (G.Rouhan et al. 925, P00684886). B. Hymenophyllum sibthorpioides (Bory ex Willd.) Mett. ex Kuhn (G.Rouhan et al. 888, P02439806). C. Didymoglossum hildebrandtii (Kuhn) Ebihara \& Dubuisson (M.Pignal et al. 3456, P02439793). D. Hymenophyllum kuhnii C.Chr. (G.Rouhan 897, P02439807). E. Crepidomanes bipunctatum (Poir.) Copel. (G.Rouhan et al. 882, P02439805). F. Hymenophyllum hirsutum (L.) Sw. (M.Pignal et al. 3487, P02439796). Photographs by G. Rouhan. Scale bars $=1 \mathrm{~cm}$. 
Table 2. Distribution of Hymenophyllaceae species in the Comoros islands, according to collects from the $19^{\text {th }}$ century to 2015 . $\mathrm{X}=$ present or reported present.

\begin{tabular}{|c|c|c|c|c|}
\hline Taxa & Anjouan & $\begin{array}{l}\text { Grande } \\
\text { Comore }\end{array}$ & Mayotte & Mohéli \\
\hline Abrodictyum pseudorigidum Bauret \& Dubuisson & $\mathrm{X}$ & $\mathrm{X}$ & & $\mathrm{X}$ \\
\hline Crepidomanes bipunctatum (Poir.) Copel. & $\mathrm{X}$ & $\mathrm{X}$ & $\mathrm{X}$ & $\mathrm{X}$ \\
\hline Crepidomanes inopinatum (Pic.Serm.) J.P.Roux & & $\mathrm{X}$ & & \\
\hline $\begin{array}{l}\text { Crepidomanes minutum (Blume) K.Iwats. var. mascarenensis } \\
\text { Pynee \& Dubuisson }\end{array}$ & $\mathrm{X}$ & $\mathrm{X}$ & $\mathrm{X}$ & \\
\hline Crepidomanes trinerve (Baker) Dubuisson \& Ebihara & & & $\mathrm{X}$ & \\
\hline Didymoglossum erosum (Willd.) J.P.Roux & $\mathrm{X}$ & & $\mathrm{X}$ & $\mathrm{X}$ \\
\hline Didymoglossum hildebrandtii (Kuhn) Ebihara \& Dubuisson & $\mathrm{X}$ & & $\mathrm{X}$ & $\mathrm{X}$ \\
\hline Didymoglossum kirkii (Hook.) Ebihara \& Dubuisson & $\mathrm{X}$ & $\mathrm{X}$ & $\mathrm{X}$ & $\mathrm{X}$ \\
\hline Didymoglossum lenormandii (Bosch) Ebihara \& Dubuisson & $\mathrm{X}$ & & $\mathrm{X}$ & \\
\hline Didymoglossum lorencei (Tardieu) Ebihara \& Dubuisson & & & $\mathrm{X}$ & $\mathrm{X}$ \\
\hline Didymoglossum robinsonii (Hook. ex Baker) Copel. & $\mathrm{X}$ & & & \\
\hline Didymoglossum rotundifolium (Bonap.) J.P.Roux & $\mathrm{X}$ & & $\mathrm{X}$ & $\mathrm{X}$ \\
\hline Hymenophyllum capense Schrad. & $\mathrm{X}$ & $\mathrm{X}$ & & \\
\hline Hymenophyllum capillare Desv. & $\mathrm{X}$ & $\mathrm{X}$ & $\mathrm{X}$ & \\
\hline Hymenophyllum hirsutum (L.) Sw. & $\mathrm{X}$ & $\mathrm{X}$ & & $\mathrm{X}$ \\
\hline Hymenophyllum inaequale (Poir.) Desv. & $\mathrm{X}$ & $\mathrm{X}$ & & \\
\hline Hymenophyllum kuhnii C.Chr. & & $\mathrm{X}$ & & $\mathrm{X}$ \\
\hline Hymenophyllum sibthorpioides (Bory ex Willd.) Mett. ex Kuhn & $\mathrm{X}$ & $\mathrm{X}$ & & $\mathrm{X}$ \\
\hline Polyphlebium borbonicum (Bosch) Ebihara \& Dubuisson & $\mathrm{X}$ & $\mathrm{X}$ & & \\
\hline Trichomanes boivinii Bosch & & & $\mathrm{X}$ & \\
\hline Vandenboschia gigantea (Bory ex Willd.) Pic.Serm. & $\mathrm{X}$ & $\mathrm{X}$ & & $\mathrm{X}$ \\
\hline Total species & 16 & 13 & 11 & 11 \\
\hline
\end{tabular}

45 out of the $111(40.5 \%)$ Comorian specimens deposited at P, while Grande Comore and Mayotte have provided $27(24.3 \%)$ and $23(20.7 \%)$ specimens, respectively, and Mohéli only three (2.7\%) specimens. Furthermore, at least 13 out of 111 (11.7\%) specimens (from the oldest collects) do not provide any other locality information than Comoros. Since 2008, 45 additional specimens have been collected representing $28.8 \%$ of the total Hymenophyllaceae collects and illustrate a significant inventory effort: seven for Anjouan, 19 for Grande Comore and 19 for Mohéli.

\section{Xper Databases}

For the Xper databases, we defined 80 descriptors (characters) for 23 items (or valid species if we consider Hymenophyllum kuhnii C.Chr. distinct from H. capense Schrad., and by including Didymoglossum cuspidatum (Willd.) Ebihara \& Dubuisson, unknown from the archipelago so far, see the discussion section, in addition to dwarf forms of $H$. capillare Desv. as distinct item). Descriptors were classified into 6 groups: habitat (1 descriptor), rhizome and roots (11 descriptors), whole frond (4 descriptors), stipe (14 descriptors), lamina (38 descriptors), and sorus (12 descriptors). The database is complete. Among the 80 descriptors, 20 are without dependencies (i.e., their presence is not conditioned by the presence of another character/descriptor), 16 are mother-descriptors and 50 depend from mother-descriptors. Six descriptors are continuous; the 74 others are qualitative or discrete. The total number of states defined for the discrete descriptors is 209 , whose minimum is 2 (binary descriptor) and maximum is 12 states (multi-state descriptor). All descriptors and states are defined and described if necessary in the database. In addition, 77 descriptors and 163 states are illustrated. The Xper2 database is available on request; the Xper3 version is available online with a free access at http://www.xper3.fr/xper3GeneratedFiles/ publish/identification/-147806907205992046/mkey.html. If this link does not work, you can request for access from the authors at dubuisson@mnhn.fr.

Some representative descriptors are illustrated in Fig. 2. The list of descriptors, states with definition and descriptions are also reported in Appendix 1. 


\title{
Taxonomic treatment
}

The nomenclatural details for each recognized species as presented here-after were partly extracted, corrected and completed from Roux (2009), and by studying the types of synonyms if available. For each species, Comorian specimens examined will be listed in the text, and specimens from other localities are reported in Appendix 2.

\author{
Class Equisetopsida C.Agardh (Agardh et al. 1825) \\ Subclass Polypodiidae Cronquist, Takht. \& W.Zimm. (Cronquist et al. 1966) \\ Order Hymenophyllales A.B.Frank (Leunis 1877) \\ Family Hymenophyllaceae Mart. (von Martius 1835)
}

\section{Genus Abrodictyum C.Presl (Presl 1843)}

This pantropical genus comprises almost 25 species which are mostly terrestrial (and a few epiphytic) ferns displaying erect, large, highly-divided fronds on a short-creeping (or long-creeping in some Asiatic species) to erect stout rhizomes bearing numerous robust roots (Fig. 4). All Comorian specimens represent only one species although they are identified as either A. rigidum (Sw.) Ebihara \& Dubuisson or $A$. cupressoides (Desv.) Ebihara \& Dubuisson. These two species are indeed commonly confused in collections. Kuhn (1868) also cited Trichomanes obscurum Blume (= Abrodictyum obscurum (Blume) Ebihara \& K.Iwats.) for Mayotte, but this species is in fact restricted to Asia and is clearly
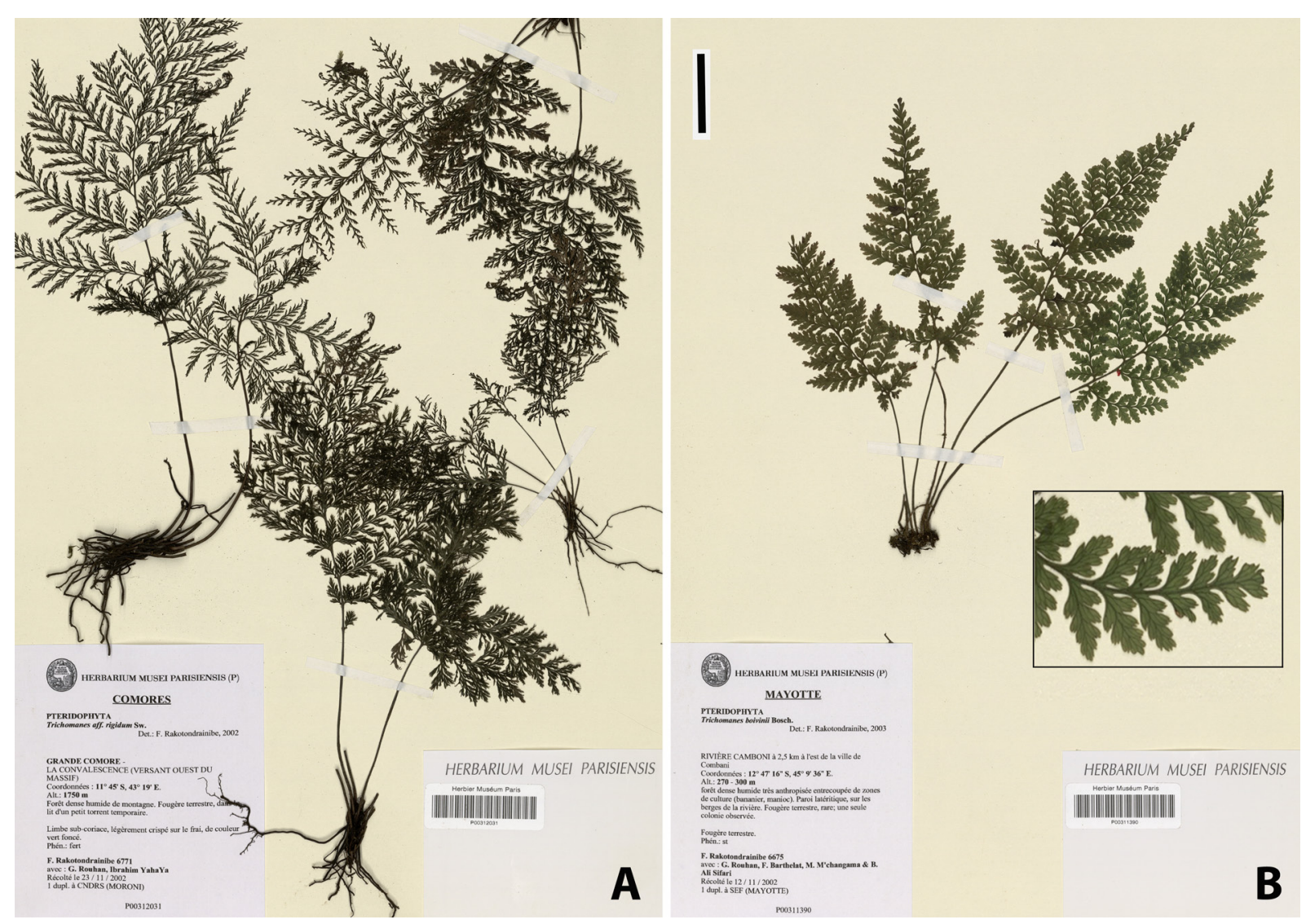

Fig. 4. Terrestrial Comorian Hymenophyllaceae. A. Abrodictyum pseudorigidum Bauret \& Dubuisson, first identified as A. rigidum (Sw.) Ebihara \& Dubuisson, (F.Rakotondrainibe et al. 6771, P00312031). B. Trichomanes boivinii Bosch, new for the archipelago according to the last inventories (as discussed in text) (F.Rakotondrainibe et al. 6675, P00311390). Scale bar for both species $=3 \mathrm{~cm}$. 
distinct even if also often confused with A. rigidum. Recent morphological and molecular studies focused on $A$. cupressoides and paleotropical $A$. rigidum evidenced that $A$. cupressoides is endemic to Seychelles and is in fact nested within the distinct genus Trichomanes (Bauret et al. 2015). Trichomanes cupressoides Desv. is thus absent from Comoros. Furthermore, specimens of the Malagasy region (including Comoros) formerly identified as $A$. rigidum actually represent a distinct species from the true neotropical $A$. rigidum (Bauret et al. 2015), and this new species has recently been described and named Abrodictyum pseudorigidum Bauret \& Dubuisson (Dubuisson et al. 2016).

\section{Abrodictyum pseudorigidum Bauret \& Dubuisson}

Abrodictyum pseudorigidum Bauret \& Dubuisson in Dubuisson et al., Phytotaxa 284: 161 (2016). Type: Madagascar, F. Rakotondrainibe 2708 (holo-: P00059914!).

'Trichomanes dregei Bosch', Nederlandsch kruidkundig archief 4: 372 (1858). - Type: South Africa, Natal, J.F. Drège s.n. (holo-: P?, not located; iso-?: S-P-18091!). Note: Van den Bosch did not provide any description for this species but only a reference to South-African Trichomanes rigidum sensu Kunze (1836) based on specimens collected by Drège. Therefore, we cannot accept this name as valid.

Trichomanes rigidum Sw. var. lugubre H.Christ, Bulletin de l'Herbier Boissier, sér. 21 (9): 849 (1901). - Type: DRC, Kisantu, J.B. Gillet s.n. (holo-: BR0000013468675!).

Trichomanes rigidum Sw. var. annobonense Brause, Botanische Jahrbücher 53: 378 (1915). - Type: Equatorial Guinea, Annobon Island, G.W.J. Mildbraed 6700 (holo-: BW200093175!).

\section{Short description}

Terrestrial or lithophytic, often near streams; thick, short and erect rhizomes with robust roots and clustered erect fronds; fronds well stipitate, up to $35 \mathrm{~cm}$ long, mostly triangular or less often sublanceolate to narrowly ovate, tripinnate-pinnatifid, with linear uni-veined ultimate segments; sori numerous, paratactic, cylindrical, truncated to slightly bilabiate with a slightly dilated mouth.

\section{Global distribution}

Tropical Africa, Comoros, Madagascar.

\section{Distribution in Comoros}

Anjouan, Grande Comore, Mohéli.

\section{Additional specimens examined}

COMOROS: s. loc., 1885, L.Humblot 1328 (P00139639, P00312496, P01430231, P01430232, P01526319, P01526320); s. loc., s.d., L.H.Boivin s.n. (P00301468). AnJouan, s. loc., May 1850, L.H.Boivin s.n. (P00139623); s. loc., 1875, M.Lavanchies.n. (P00139638); s. loc., 1875, J.M.Hildebrandt 1793 (P00139637); Mjimandra, 1 Apr. 2011, E.Bidault et al. 109 (P02439773). Grande Comore, La Convalescence, versant ouest, 23 Nov. 2002, F.Rakotondrainibe et al. 6771 (P00312031); versant ouest du volcan Karthala, bois proche de Convalescence, 24 Oct. 2008, M.Pignal et al. 3381 (P02439785), M.Pignal et al. 3391 (P02439789). MohÉLI, Forêt de Saint Antoine, 21 Sep. 1995, N.Moulaert F.099 (P01485567); Chalet St Antoine, 5 Nov. 2008, M.Pignal et al. 3473 (P00684891).

\section{Genus Crepidomanes (C.Presl) C.Presl (Presl 1849)}

This genus is mostly paleotropical with more than 25 species including two taxa in Americas (Dubuisson et al. 2013b). All species are epiphytic or lithophytic, dwarf to medium-size plants characterized by long-creeping, filiform and rootless rhizomes bearing pending flabellate (for the smallest) to highly divided (for the largest) fronds. The marginal sori have a tubular base and lips more or less developed (see Fig. 2C). In addition, laminae often exhibit false veins (Fig. 2E) or folds imitating veins. 


\section{Crepidomanes bipunctatum (Poir.) Copel.}

Crepidomanes bipunctatum (Poir.) Copel., The Philippine Journal of Science 67: 59 (1938). - Trichomanes bipunctatum Poir., Encyclopédie méthodique, Botanique 8: 69 (1808). - Type: Madagascar, s. loc., s.d., L.-M.A. du Petit-Thouars s.n. (holo-: P00482602!; iso-: P00477821!, P00477823!).

Didymoglossum bipunctatum (Poir.) E.Fourn., Annales des Sciences naturelles, Botanique, sér. 5, 18: 263 (1873).

Hymenophyllum filicula Bory ex Willd., Species plantarum: 528 (1810). - Type: 'Habitat in sylvis insulae Mauritii, Borboniae', s.d., J.B.G.M. Bory de St.-Vincent s.n. (holo-: BW20233010!; iso-: P00477824!). Trichomanes filicula (Bory ex Willd.) Bory, Voyage autour du monde. Cryptogamie 6: 283 (1829). Taschneria filicula (Bory ex Willd.) C.Presl, Abhandlungen der Königlichen Böhmischen Gesellschaft der Wissenschaften, ser. 5, 6: 618 (1851).

\section{Short description}

Epiphytic or less often lithophytic; long-creeping filiform rhizomes, rootless and densely covered by dense black trichomes, bearing widely separated pending fronds; fronds with fully winged stipes, up to $12 \mathrm{~cm}$ long, lanceolate to ovate, less often triangular, pinnate-pinnatifid to bipinnate-pinnatifid with false veins more or less continuous, parallel to the margin and not connected to true veins; sori numerous, paratactic, with obconic to campanulate base and triangular lips.

\section{Global distribution}

Western Indian Ocean to Pacific Ocean.

\section{Distribution in Comoros}

Anjouan, Grande Comore, Mayotte, Mohéli.

\section{Additional specimens examined}

COMOROS: Anjouan, s. loc., May 1850, L.H.Boivin s.n. (P0013962); s. loc., 1875, J.M.Hildebrandt 1850 (P00433461, P01331089, P01331092); s. loc., 1905, M.Lavanchie s.n. (P01331094). GRANDE Comore, Forêt de la Grille, May 1850, L.H.Boivin s.n. (P01331087); s. loc., May 1963, J.Bosser 17981 (P00139618); Centre Sud, forêt dense au NE de Kourani, 24 Feb. 1975, J.J.Floret 914 (P00139622); Massif de La Grille, bord de la piste menant au pylône, 9 Nov. 2008, M.Pignal et al. 3511 (P02439797). Mayotte, Réserve forestière de Benara, Sommet du Bepilipili, 28 Nov. 2000, J.N.Labat et al. 3305 (P00220428); GR du Bénara près du chemin de crête, 22 Sep. 2001, M.Pignal et al. 1930bis (P00229663); Réserve forestière de Benara, 22 Aug. 2002, F.Barthelat 1000 (P00290459); E.Marie s.n. (P00139619); Massifs de Benara et de Bépilipili, Chemin de crête reliant les deux massifs, 9 Sep. 2002, F.Rakotondrainibe et al. 6650 (P00310477); Mavegani, s.d., E.Marie 191 (P00411765). MoHÉLI, Voundrouvou, Chalet Saint Antoine, 25 Nov. 1999, J.N.Labat et al. 3218 (P00184120); Piste entre Miringoni et le Chalet St Antoine, 4 Nov. 2008, G.Rouhan et al. 872 (P02439803), G.Rouhan et al. 882 (P02439805); Chalet St Antoine, 5 Nov. 2008, M.Pignal et al. 3475 (P02439794); Au-dessus de Drondroni, 26 Mar. 2011, C.Loup et al. 577 (P02439781).

\section{Note}

Among the four Crepidomanes taxa recognised in Comoros, the widespread C. bipunctatum is an easily distinguishable species. It displays typical lamina false veins more or less continuous and parallel to margins and the sorus lips are triangular (a unique feature for the Comorian Hymenophyllaceae) (see Figs 2E, 3E). This is also one of the only two Hymenophyllaceae species reported on all the four islands with Didymoglossum kirkii (see Table 2). 
Crepidomanes inopinatum (Pic.Serm.) J.P.Roux

Crepidomanes inopinatum (Pic.Serm.) J.P.Roux, Conspectus of southern African pteridophyta: 45 (2001). - Vandenboschia inopinata Pic.Serm., Bulletin du Jardin botanique national de Belgique 53, 1/2: 245, 246 (1983).- Type: DRC, s. loc., s.d., R.E.G. Pichi Sermolli 4455 (holo-: FI-PS 19455; iso-: K000435648!, BR 0000008054661!).

Trichomanes inopinatum (Pic.Serm.) J.E.Burrows, Southern African ferns and fern allies: 93 (1990).

Trichomanes pyxidiferum L.f. majus Taton, Bulletin de la Société royale de Botanique de Belgique 78: 34 (1946). - Type: DRC, s. loc., s.d., J.C.C. Bequaert 3931bis (syn-: BR 0000013208462!); DRC, s. loc., s.d., J.C.C. Bequaert 4231 (syn-: BR 0000013204853!); DRC, s. loc., s.d., J.C.C. Bequaert s.n. (syn-: BR 0000013204877!); DRC, s. loc., s.d., J.C.C. Bequaert s.n. (syn-: BR 0000013204860!).

\section{Short description}

Epiphytic or lithophytic; long-creeping filiform rhizomes, rootless and densely covered by dense black trichomes, bearing widely separated pending fronds; fronds well stipitate, with wing on the upper part of the stipe, up to $10(-15) \mathrm{cm}$ long, lanceolate to ovate, pinnate-pinnatifid to bipinnate-pinnatifid with sometimes, when dry, folds parallel to veins; sori numerous, paratactic, mostly as long as wide, obconic to campanulate with a slightly dilated mouth.

\section{Global distribution}

Central Africa to the western Indian Ocean.

\section{Distribution in Comoros}

Grande Comore.

\section{Additional specimens examined}

COMOROS: Grande Comore, Massif de la Grille, 30 Nov. 2002, F.Rakotondrainibe et al. 6841, 6841 bis (P00312119, P00312120).

\section{Note}

The medium-sized (with bipinnate-pinnatifid fronds usually up to $10 \mathrm{~cm}$ long, rarely longer) C. inopinatum is usually found in highland rainforests from Central Africa to the western Indian Ocean (Kornaś 1994) and is here newly reported from the Comoros. It is often confused with the morphologically closely related C. melanotrichum (Schltdl.) J.P.Roux which differs only by the dense and black indumentum all along the stipe (vs restricted to the stipe base in $C$. inopinatum). Such confusion explains that the BR isotype specimen (BR 0000008054661) was identified on the sheet as C. melanotrichum by Beentje in 2007. The two existing Comorian collects do not exhibit the particular dense indumentum all along the stipe suggesting that they should rather represent $C$. inopinatum. But as discussed by Dubuisson et al. (2013b), the distinction between C. inopinatum and C. melanotrichum based on stipe indumentum is not always obvious and thus questionable.

Crepidomanes minutum (Blume) K.Iwats. var. mascarenensis Pynee \& Dubuisson

Crepidomanes minutum (Blume) K.Iwats. var. mascarenensis Pynee \& Dubuisson in Pynee et al., Phytotaxa 62: 28 (2012). - Type: Mauritius, Mt. Lagrave, 18 Jan. 1974, D. Lorence s.n. (holo-: MAU0009282 !). 


\section{Short description}

Epiphytic; long-creeping filiform rhizomes, rootless and densely covered by dense black trichomes, bearing widely separated pending fronds; fronds with terete wingless stipes, and rare proliferation, up to $2.5 \mathrm{~cm}$ long, flabellate, palmatisect to digitate (less often pinnatifid), with sometimes, when dry, folds parallel to veins; sori few, paratactic, tubular to funnelform with a slightly dilated mouth.

\section{Global distribution}

Western Indian Ocean (the type variety is widespread from Africa to Pacific islands).

\section{Distribution in Comoros}

Anjouan, Grande Comore, Mayotte.

\section{Additional specimens examined}

COMOROS: Anjouan, s. loc., 1850, L.H.Boivin s.n. (P00139635). Grande Comore, Forêt de la Grille, May 1963, J.Bosser 17982 (P00139636). MаYotTe, s. loc., 1882, E.Marie s.n. (P00139634).

\section{Note}

The dwarf C. minutum (with digitate to flabellate fronds that rarely exceed $3 \mathrm{~cm}$ long) is usually distinguished by the presence of buds on stipes which can develop to provide a new frond, a feature called 'stipe proliferation' (the synapomorphy of sect. Gonocormus; Ebihara et al. 2006). However, the Comorian specimens do not exhibit such features. They could thus correspond to $C$. minutum var. mascarenensis that describes lowland populations of dwarf specimens without proliferation (Pynee et al. 2012).

\section{Crepidomanes trinerve (Baker) Dubuisson \& Ebihara}

Crepidomanes trinerve (Baker) Dubuisson \& Ebihara in Dubuisson et al., Acta Botanica Gallica, Botany Letters 160: 187 (2013b).- Trichomanes trinerve Baker, Flora of Mauritius and the Seychelles: 465 (1877). - Type: Mauritius, s. loc., s.d., H. Barkly and A.M. Barkly s.n. (holo-: K000228373!).

Trichomanes ambongoense Bonap., Notes ptéridologiques 9: 13 (1920a). - Type: Madagascar, s. loc., s.d., H.Perrier de la Bâthie 7501 (lecto-: P00466414!; isolecto-: P00466408!, designated by Dubuisson et al. 2013b); s. loc., s.d., H.Perrier de la Bâthie 7769 (syn-: P00466412!, P00466413!); s. loc., s.d., H.Perrier de la Bâthie 7770 (syn-: P00466410!, P00466411!); s. loc., s.d., H.Perrier de la Bâthie 7771 (syn-: P00466409!, P00482601!).

Trichomanes angustilaciniatum Bonap., Notes ptéridologiques 16: 11 (1925). - Type: Madagascar, s. loc., s.d., H.Perrier de la Bâthie 13756 (holo-: P00482604!; iso-: P00482603!).

\section{Short description}

Lithophytic, less often epiphytic; long-creeping filiform rhizomes, rootless and densely covered by dense black trichomes, bearing widely separated pending fronds; fronds with slightly winged stipes, up to $3.5(-5) \mathrm{cm}$ long, flabellate to obovate, palmatisect to digitate, less often pinnatifid, with always, when dry, folds parallel to veins; sori few, paratactic, campanulate with a well dilated mouth.

\section{Global distribution}

Comoros, Madagascar, Mauritius, La Réunion.

\section{Distribution in Comoros}

Mayotte. 


\section{Additional specimens examined}

COMOROS: Mayotte, Massif de Benara et Bépilipili, chemin de crête reliant les deux massifs, 9 Nov. 2002, F.Rakotondrainibe et al. 6651 (P00310478); Mont Tchaourembo, 13 Nov. 2002, F.Rakotondrainibe et al. 6682 (P00311398). NB: these specimens were used for the molecular phylogeny in Dubuisson et al. (2013b).

\section{Note}

Crepidomanes trinerve is often confused with the distinct $C$. minutum, the first being even considered as a synonym of the latter by Roux (2009). Both taxa are nevertheless clearly distinct based on the stipe which is terete and wingless in C. minutum and slightly but always winged in C. trinerve in addition to some sorus features (Dubuisson et al. 2013b). Crepidomanes trinerve, initially considered as endemic to Mauritius, is thus also present in Comoros (and in Madagascar and La Réunion).

\section{Genus Didymoglossum Desv. (Desvaux 1827)}

The most diversified genus in the archipelago (7 spp.) is pantropical and clusters more than 30 species which are epiphytic or lithophytic, minute to medium-sized with long-creeping and rootless rhizomes bearing fronds that are usually entire to lobed and in some cases pinnatifid (rarely bi-pinnatifid to bipinnate). The laminae exhibit false veins parallel to true veins, at least for the Comorian species (Fig. 2B, 2D). The two described subgenera Didymoglossum and Microgonium (C.Presl) Ebihara \& K.Iwats. are represented in the Comoros by three and four species, respectively.

\section{Subgenus Didymoglossum}

Except Didymoglossum hildebrandtii (Kuhn) Ebihara \& Dubuisson, the Comorian species belonging to subg. Didymoglossum share hairy lamina margins and emersed sori with tubular base and bilabiate lips with brown margin.

\section{Didymoglossum hildebrandtii (Kuhn) Ebihara \& Dubuisson}

Didymoglossum hildebrandtii (Kuhn) Ebihara \& Dubuisson in Ebihara et al., Blumea 51: 236 (2006).Trichomanes hildebrandtii Kuhn, Von der Decken's Reisen in Ost-Afrika in 1859 bis 1861 3(3) Botanik: 70 (1879). - Type: 'Johanna Isl.', s. loc., s.d., J.M. Hildebrandt 1856 (holo-: K000435634!; iso-: P00139629!).

\section{Short description}

Epiphytic; long-creeping filiform rhizomes, rootless and densely covered by dense black trichomes, bearing widely separated fronds; fronds sessile and peltate, up to $6 \mathrm{~cm}$ long, mostly round and entire, with false veins parallel to true veins and palmate venation; sori numerous, pantotactic, cylindrical with a truncated mouth.

\section{Global distribution}

Comoros, Madagascar.

\section{Distribution in Comoros}

Anjouan, Mayotte, Mohéli.

\section{Additional specimens examined}

COMOROS: AnJouan, s. loc., 1905, Lavanchie s.n. (P00139628). Mayotte, Massif de Mtsapéré, Maison de la Convalescence, 10 Nov. 2002, F.Rakotondrainibe et al. 6669 (P00311382). MoHÉLI, Kidogobassi, 
2 Nov. 2008, M.Pignal et al. 3456 (P02439793); Au-dessus de Drondroni, 26 Mar. 2011, C.Loup et al. 590 (P02439783); Au-dessus de Drondroni, 27 Mar. 2011, E.Bidault et al. 81 (P02439772).

\section{Note}

Didymoglossum hildebrandtii is clearly distinct with round and sessile peltate fronds which seem tightly appressed against the substrate (Fig. 3C). These features, unique for the family in the region, are shared with the Pacific and Asiatic D. tahitense (Nadeaud) Ebihara \& K.Iwats. to which it is evolutionary closely related (Ebihara et al. 2007).

\section{Didymoglossum lorencei (Tardieu) Ebihara \& Dubuisson}

Didymoglossum lorencei (Tardieu) Ebihara \& Dubuisson in Ebihara et al., Blumea 51: 236 (2006). Trichomanes lorencei Tardieu, Adansonia, sér. 2, 17 (2): 147, pl. 1, t. 7-13 (1977). - Type: Mauritius, D.H. Lorence 1175 (holo-: P00477828!).

\section{Short description}

Epiphytic or lithophytic; long-creeping filiform rhizomes, rootless and densely covered by dense black trichomes, bearing widely separated pending fronds; fronds sessile to subsessile, up to $1.5 \mathrm{~cm}$ long, oblong to obovate, entire with entire to undulate margins, with palmate venation and false veins parallel to true veins, hairy with dark not pedunculated trichomes on lamina margins; one single terminal sorus per fertile frond, cylindrical with lips usually parallel and with brown margins.

\section{Global distribution}

Comoros, Madagascar, Mauritius, La Réunion.

\section{Distribution in Comoros}

Mayotte, Mohéli.

\section{Additional specimens examined}

COMOROS: Mayotte, Mont Tchaourembo à $2.5 \mathrm{~km}$ au SE de la ville de Ouangani, 13 Nov. 2002, F.Rakotondrainibe et al. 6688 (P00311404). MohéLI, Piste entre Miringoni et le Chalet St Antoine, 4 Nov. 2008, G.Rouhan et al. 874 (P00684865).

\section{Note}

Didymoglossum lorencei has simple and entire fronds bearing marginal starred hairs and always a single sorus, while the morphologically close D. robinsonii (Hook. ex Baker) Copel. (presented here-after) has fronds often lobed to pinnatifid (see Fig. 2B) and often more than one sorus.

Didymoglossum robinsonii (Hook. ex Baker) Copel.

Didymoglossum robinsonii (Hook. ex Baker) Copel., The Philippine Journal of Science 67: 77, t. 31, figs 7, 8 (1938). - Trichomanes robinsonii Hook. ex Baker, Journal of the Linnean Society, Botany 9: 339, t. 8B (1866), as 'robinsoni' - Type: Natal, E.A. Robinson s.n. (syn-: K000435669!, K000435670!); Natal, J. Sanderson s.n. (syn-: K000435671!).

Trichomanes reptans Sw. var. major Mett. ex Kuhn, Filices Africanae: 37 (1868). - Type: 'Natalia', s. loc., s.d., s. coll. s.n. (Herb. Hooker). 


\section{Short description}

Epiphytic; long-creeping filiform rhizomes, rootless and densely covered by dense black trichomes, bearing widely separated pending fronds; fronds subsessile or with short stipes, up to $5 \mathrm{~cm}$ long, oblong to ovate, lobed to pinnatifid, with palmate to pinnate venation and false veins parallel to true veins, hairy with dark not pedunculated trichomes on lamina margins; sori few, epitactic, cylindrical with lips usually parallel and with brown margins.

\section{Global distribution}

Comoros, Madagascar, Tanzania, South Africa.

\section{Distribution in Comoros}

Anjouan.

\section{Additional specimen examined}

COMOROS: ANJouAn, les forêts des sommets les plus élevées, May 1850, L.H. Boivin s.n. (P02439524).

\section{Note}

African Didymoglossum robinsonii is morphologically quite close to D. reptans (Sw.) C.Presl and as such was considered a synonym of the latter species (Wessels Boer 1962; Roux 2009). In addition, paleotropical $D$. reptans has often been identified as D. montanum (Hook.) J.P.Roux, especially by Sim (1915) or Tardieu-Blot (1951). Types of D. reptans and D. montanum are both neotropical, and exhibit identical diagnostic characters, explaining why we consider that these two taxa are synonyms $(D$. reptans has priority) as previously considered by Wessels Boer (1962). By considering such synonymy and the a priori of paleotropical D. reptans populations, D. reptans would be present in Neotropics, in eastern and southern Africa and in the western Indian Ocean, but would be absent in western and central Africa (according to collections and Roux 2009). However, unpublished personal molecular data (based on $r b c \mathrm{~L}$ sequences) would indicate that neotropical $D$. reptans would be genetically close and yet distinct from paleotropical specimens from Madagascar and Comoros (i.e., they do not form a monophyletic cluster). The disjunct distribution and the genetic differences thus suggest that Comorian supposed D. reptans (often identified as $D$. montanum) could be a distinct species and thus likely considered D. robinsonii (type from South Africa) as a distinct (potentially cryptic) taxon and not a synonym of D. reptans. Additional molecular phylogenetic investigations including African specimens are required to clarify the taxonomic status of the paleotropical populations. Pending such revision we name the Comorian species D. robinsonii.

\section{Subgenus Microgonium}

Subgenus Microgonium is represented by four species. All Comorian species have glabrous lamina margins, submarginal false veins and sori more or less immerged in the laminae with tubular base and lips more or less developed, sometimes dilated as a collar but never bilabiate, and with undifferentiated margins. The widespread D. cuspidatum was cited for the archipelago in literature (Roux 2009) but represented in collection by only four specimens. This contradicts its supposed abundance in the region, as well observed in Mascarenes (pers. obs.; Grangaud 2010). In addition the species is usually distributed from sea level up to $1350-1400 \mathrm{~m}$, and more frequently below $1000 \mathrm{~m}$. All the supposedly Comorian specimens (including recent collects firstly identified as D. cuspidatum) were collected at high elevations, above $1000 \mathrm{~m}$. A precise investigation of these specimens reveals in fact that they are not D. cuspidatum but rather the distinct D. erosum (Willd.) J.P.Roux. Didymoglossum cuspidatum would be absent in Comoros but confusion with D. erosum as detailed here-after remains easy. This explains why we, however, chose to maintain D. cuspidatum in the Xper database, in order to allow its potential identification in future collects. 


\section{Didymoglossum erosum (Willd.) J.P.Roux}

Didymoglossum erosum (Willd.) J.P.Roux, Strelitzia 22: 212 (2008). - Trichomanes erosum Willd., Species plantarum: 501 (1810). - Type: 'Habitat in Oware et Benin', A.M.F.J. Palisot de Beauvois s.n. (holo-: BW20189010!; iso-: P00064998!).

Microgonium erosum (Willd.) C.Pres1, Abhandlungen der Königlichen Böhmischen Gesellschaft der Wissenschaften: 335 (1848).

Trichomanes erosum Willd. var. laciniatum Mett. ex Peter, Feddes Repertorium, Beiheft 40 (1): 12 (1929). - Type: 'Comoren: Ins. Johanna', s.d., s. coll. s.n. (not located); 'DOAfr., Ousambara', s.d., A. Peter 3339 (not located).

Trichomanes aerugineum Bosch, Nederlandsch Kruidkundig Archief 5: 201 (1861). - Type: Fernando Po, C. Barter s.n. (holo-: K000435654!; iso-: K000435653!).

Trichomanes erosum (Willd.) var. aerugineum Bonap., Notes ptéridologiques 13: 165 (1921).

Microgonium aerugineum (Bosch) Pic.Serm., Webbia 23: 181 (1968).

Trichomanes palmicola Bosch ex Goddijn, Mededeelingen van 's Rijks-Herbarium 17: 32, fig. 19 (1913).

- Type: Nigeria, C. Barter 2079 (lecto-: L; isolecto-: K000435655!, designated by Pichi Sermolli 1982).

Trichomanes hookeri Bonap. var. cordifolium (Fée) Bonap., Notes ptéridologiques 10: 30 (1920b), non

C.Presl (1843: 16).

\section{Short description}

Epiphytic; long-creeping filiform rhizomes, rootless and densely covered by dense black trichomes, bearing widely separated pending fronds; fronds subsessile to well stipitate, up to $1.5 \mathrm{~cm}$ long (in Comoros, longer in Continental Africa), ovate or obovate to elliptic, entire to lobed, with palmate venation, and false veins parallel to true veins in addition to a submarginal false vein; sori few, epitactic, campanulate with a slightly dilated mouth.

\section{Global distribution}

Comoros, Madagascar, Tropical Africa.

\section{Distribution in Comoros}

Anjouan, Mayotte, Mohéli.

\section{Additional specimens examined}

COMOROS: Anjouan, s. loc., 1850, L.H.Boivin s.n. (P00139625, P00139626). MayotTE, s. loc., 1882, E.Marie s.n. (P00139627); Massif du Bénara, crête entre les 2 sommets, 23 Feb. 2015, G.Rouhan et al. 1470 (P02439036), G.Rouhan et al. 1471 (P02439037). MohéLI, Chalet Saint Antoine, 5 Nov. 2008, M.Pignal et al. 3484 (P00684897); Piste de Ouala à Fomboni, 28 Mar. 2011, G. Viscardi et al. 419 (P02439809).

\section{Note}

Didymoglossum erosum is one out of the two smallest Hymenophyllaceae species in the archipelago with $D$. rotundifolium. The lamina length exceeds $1.2 \mathrm{~cm}$ long and is slightly larger than observed in D. rotundifolium (see here-after), at least for specimens of the western Indian Ocean because continental African specimens (especially in Western Africa) can reach 3-4 cm long. Fronds are also subsessile to well stipitate, entire to lobed, ovate, obovate or elliptic. Confusion can easily be made with small fertile $D$. cuspidatum (unknown in the archipelago) exhibiting equivalent lamina shape. However, in D. erosum, sori are mostly and clearly well immersed into frond lamina, while in D. cuspidatum each sorus appears quite often well included into a distinct small winged lobe. 
Didymoglossum kirkii (Hook.) Ebihara \& Dubuisson

Didymoglossum kirkii (Hook.) Ebihara \& Dubuisson in Ebihara et al., Blumea 51: 236 (2006). Trichomanes kirkii Hook. in Hooker \& Baker, Synopsis filicum 3: 78 (1867). - Type: 'Comoro Isl., Johanna Isl.', J. Kirk s.n. (holo-: K000435666!).

Crepidomanes seu Microgonium kirkii (Hook.) Copel., The Philippine Journal of Science 67: 104 (1938), nom. nud. Note: these combinations were never validly published but just suggested in a synonym list by Copeland, and were nevertheless cited by Tardieu-Blot (1951).

\section{Short description}

Lithophytic or epiphytic; long-creeping filiform rhizomes, rootless and densely covered by dense black trichomes, bearing widely separated pending fronds; fronds well stipitate, up to $9 \mathrm{~cm}$ long, lanceolate to obovate, entire with undulate margins to mostly pinnate, less often pinnate-pinnatifid or bipinnate, with pinnate venation, and false veins parallel to true veins in addition to a submarginal false vein; few sori at the apex of pinnae, epitactic, cylindrical with a slightly dilated mouth.

\section{Global distribution}

Comoros.

\section{Distribution in Comoros}

Anjouan, Grande Comore, Mayotte, Mohéli.

\section{Additional specimens examined}

COMOROS: [Anjouan?], s. loc., 1886, L.Humblot 1552 (P00139630, P00139631, P00139632, P00312476). Anjouan, s. loc., May 1850, LH.Boivin s.n. (P00301470, P00301471); s. loc., 1905?, M.Lavanchie s.n. (P00301469). Grande Comore, Base du Massif du Karthala, 10 Jun. 2006, J.-N.Labat et al. 3807 (P00527430); Versant ouest du volcan Karthala, bois proche de Convalescence, 24 Oct. 2008, M.Pignal et al. 3401 (P02439792); Massif forestier à l'ouest de la route régional 125 (départ de la piste à 2-3 km au sud de Tsinimouapanga), 10 Nov. 2008, G.Rouhan et al. 925 (P00684886). МАYOTTE, Qualey, Aug. 1847, L.H.Boivin 2883 (P00312471); Combani, Le long du Mroni Mouala, 17 Apr. 1999, M.Pignal et al. 1209 (P00139596); Rivière Camboni, 12 Nov. 2002, F.Rakotondrainibe et al. 6673 (P00311387). MohéLI, Piste entre Miringoni et le Chalet St Antoine, 4 Nov. 2008, G.Rouhan et al. 879 (P02439804); Chalet St Antoine, 5 Nov. 2008, M.Pignal et al. 3485 (P02439795).

\section{Note}

Didymoglossum kirkii, the only Hymenophyllaceae endemic to the Comoros, is the largest Comorian Didymoglossum species with fertile stipitate fronds up to $9 \mathrm{~cm}$ long which are entire or most often pinnatifid, or pinnate to bipinnate (Fig. 3A). In addition, rachises are often clearly distinct in $D$. kirkii compared to other Didymoglossum species.

\section{Didymoglossum lenormandii (Bosch) Ebihara \& Dubuisson}

Didymoglossum lenormandii (Bosch) Ebihara \& Dubuisson in Ebihara et al., Blumea 51: 236 (2006). Trichomanes lenormandii Bosch, Nederlandsch Kruidkundig Archief 5 (3): 144 (1861), as 'lenormandi'. - Type: 'Hab. Ins. Mayotta pr. oras Africae australes', L.H. Boivin s.n., Herb. de Limminghe (BR).

Trichomanes lenormandii Bosch var. angustilobum C.Chr. in Bonaparte, Notes ptéridologiques 9: 20 (1920a), as 'angustiloba'. - Type: Madagascar, Massif de Manongarivo, H.Perrier de la Bâthie 7732 (holo-: P00466419!; iso-: P00466420!); Madagascar, Massif de Manongarivo, H.Perrier de la Bâthie 7738 A p.p. (syn-: P00482639!). 
Trichomanes lenormandii Bosch var. subcuspidatum C.Chr. in Bonaparte, Notes ptéridologiques 9: 21 (1920a). - Type: Madagascar, Grande Terre, H.Perrier de la Bâthie 7733 (holo-: P00466418!; iso-: P00466417!).

\section{Short description}

Lithophytic or epiphytic; long-creeping filiform rhizomes, rootless and densely covered by dense black trichomes, bearing widely separated pending fronds; fronds well stipitate, up to $6 \mathrm{~cm}$ long, linear to oblong, less often lanceolate to ovate, entire with undulate margins to pinnatifid, less often pinnate, with palmate to pinnate venation, and false veins parallel to true veins in addition to a submarginal false vein; numerous sori at the apex of lateral lobes, epitactic, cylindrical with a slightly dilated mouth.

\section{Global distribution}

Comoros, Madagascar, Tanzania.

\section{Distribution in Comoros}

Anjouan, Mayotte.

\section{Additional specimens examined}

COMOROS: Anjouan, Sommets élevés et boisés d'Anjouan, May 1850, L.H.Boivin s.n. (P01522381, only drawings). MAYotTE, Qualey, Aug. 1849, L.H.Boivin 2883 (P00139633).

\section{Note}

The specimen P00466419 of Trichomanes lenormandii var. angustilobum, although not mentioned as the holotype in the original description, must be accepted as the holotype because the author of the name (Christensen) clearly used only this sheet (Art. 9.1, Note 1, McNeill et al. 2012) as stated by Bonaparte who mentioned on the sheet 'Spécimens envoyés à $\mathrm{M}$. Christensen. Retour avec sa lettre du 23 Août 1919' and by the handwritten label by Christensen stating the specimen as a new variety. The same reasons explain the holotype specimen of $T$. lenormandii var. subcuspidatum. Futhermore, D. lenormandii is highly variable in terms of frond shape and division. Both varieties, angustilobum and subcuspidatum, illustrate such an infra-specific variability and are thus considered here as synonyms.

Didymoglossum lenormandii, with entire pinnatifid laminae, is smaller than $D$. kirkii with fronds up to $6 \mathrm{~cm}$ long. In addition, the number of sori exceptionally exceeds 6 per fertile frond in D. kirkii and each sorus is mostly located at the extremity of a long segment, while $D$. lenormandii exhibits usually 6 or much more sori per frond, which are born on short lateral lobes. Didymoglossum lenormandii can nevertheless be confused, especially the sterile fronds, with $D$. cuspidatum (unknown in the archipelago) because they often share the same gross lamina shape with undulated to lobed margins. But as for $D$. kirkii, sori of $D$. cuspidatum rarely exceed 6 per frond and they are apically located on ovate to obovate or deltoid fronds while they are mostly born on lateral lobes of oblong to lanceolate fronds in D. lenormandii.

\section{Didymoglossum rotundifolium (Bonap.) J.P.Roux}

Didymoglossum rotundifolium (Bonap.) J.P.Roux, Strelitzia 23: 42 (2009). - Trichomanes rotundifolium Bonap., Notes ptéridologiques 9: 23 (1920a). - Type: Madagascar, Massif de Manongarivo, s.d., H.Perrier de la Bâthie 7735 (lectotype, here designated: hololecto-: P00482612!; isolecto-: P00477780!, P00482613!); Madagascar, Massif de Manongarivo, s.d., H.Perrier de la Bâthie 7442 p.p. (syn-: $\mathrm{P} 00482611$ !). 


\section{Short description}

Lithophytic or epiphytic; long-creeping filiform rhizomes, rootless and densely covered by dense black trichomes, bearing widely separated pending fronds; fronds sessile to subsessile, up to $0.7(-1) \mathrm{cm}$ long, round to oblong, or ovate, entire with entire to undulate margins, with palmate to slightly pinnate venation, and false veins parallel to true veins in addition to a submarginal false vein; mostly a single terminal sorus per fertile frond, rarely more, and epitactic, campanulate with a slightly dilated mouth.

\section{Global distribution}

Madagascar, Comoros.

\section{Distribution in Comoros}

Anjouan, Mayotte, Mohéli.

\section{Additional specimens examined}

COMOROS: Anjouan, s. loc., 1875, J.M.Hildebrandt s.n. (P00347524). Mayotte, Massif de Mtsapéré, Maison de la Convalescence, 10 Nov. 2002, F.Rakotondrainibe et al. 6670 (P00311383); Mont Tchaourembo, 13 Nov. 2002, F.Rakotondrainibe et al. 6681 (P00311397). MoнÉLI, Chalet St Antoine, 5 Nov. 2008, M.Pignal et al. 3484 (P00684897).

\section{Note}

The sheet P00482612, included in the original material, consists of many individuals with several fertile fronds, and specimens are representative of the morphology of the species. Moreover, this sheet was probably intended to be the holotype, as indicated by the handwritten annotation 'Original' by Bonaparte. For all these reasons, P00482612 was selected as the lectotype specimen for T. rotundifolium.

Didymoglossum rotundifolium is the smallest Comorian Hymenophyllaceae species with sessile to subsessile, round to oblong, entire fronds (never lobed contrary to D. erosum), and laminae up to $0.7-1 \mathrm{~cm}$ long (see Fig. 2D).

\section{Notes on genus Didymoglossum in Comoros}

Didymoglossum lorencei, D. robinsonii and D. erosum are new for the archipelago. They were never reported, likely due to confusions with morphologically close taxa. We can, however, note here that D. erosum, absent in the archipelago according to Tardieu-Blot (1951) and Roux (2009), would be nevertheless present according to the type of Trichomanes erosum var. laciniatum which would have been collected in Comoros. But this type specimen could not be observed nor studied, and its identification remains questionable. Sterile $D$. erosum is also indeed easily confused with small sterile $D$. cuspidatum. The confusion is also easy between $D$. rotundifolium and small $D$. erosum specimens with entire laminae. The first species never displays lobed fronds contrary to the second. Didymoglossum lorencei and $D$. robinsonii are often found growing as epiphyte and mixed and confused with other species of Didymoglossum. Only microscopic observation of marginal hairs allows the distinction. It explains that the occurrence of $D$. lorencei in La Réunion has been reported only recently, because the species is quite discrete and mostly grows on tree-fern trunks in association with the much more abundant D. cuspidatum (pers. obs.; Grangaud 2010).

\section{Genus Hymenophyllum Sm. (Smith 1793)}

This pantropical genus (in addition to numerous species in wet temperate areas, especially in southern hemisphere) regroups more than 300 epiphytic (more rarely lithophytic), dwarf to large species with mostly long-creeping filiform rhizomes bearing sparsely distributed roots and pending dissected fronds 
in addition to sori without developed tubular base (at least for species of the region; Fig. 2A, F). In the Comoros, species belong to three subgenera following Ebihara et al. (2006): Hymenophyllum, Sphaerocionium (C.Presl) C.Chr. and Mecodium C.Presl ex Copel.

\section{Subgenus Hymenophyllum}

Subgenus Hymenophyllum is represented in Comoros by a single well-identifiable species: H. sibthorpioides (Bory ex Willd.) Mett. ex Kuhn. This small species displays particular flabellate fronds and toothed sorus lip margins (Figs 2F, 3B).

\section{Hymenophyllum sibthorpioides (Bory ex Willd.) Mett. ex Kuhn}

Hymenophyllum sibthorpioides (Bory ex Willd.) Mett. ex Kuhn, Filices Africanae: 41 (1868). Trichomanes sibthorpioides Bory ex Willd., Species plantarum: 498 (1810). - Type: 'Habitat in insula Borboniae', J.B.G.M. Bory de St.-Vincent s.n. (holo-: BW20204010!; iso-: P00612300!).

Trichomanes parvulum Poir., Encyclopédie méthodique, Botanique 8: 64 (1808), non Copel. (1933: 145), nec auct. - Type: 'L'île de Madagascar', L.-M.A. du Petit-Thouars s.n. (holo-: P00065014!; iso-: P00065015!).

Microtrichomanes parvulum (Poir.) Copel., The Philippine Journal of Science 67: 37 (1938).

Trichomanes flabellatum Bory ex Desv., Mémoires de la Société linnéenne de Paris 6 (2): 325 (1827), nom. nud. - Type: Cites Trichomanes flabellula d'Urv., Mémoires de la Société linnéenne de Paris 4: 597 (1824).

Trichomanes thouarsianum C.Presl, Eine botanische Abhandlung: 40 (1843). - Type: 'Habitat in insula Borbonia', L.-M.A. du Petit-Thouars s.n. (not located).

Hymenophyllum palmatum Bosch, Nederlandsch Kruidkundig Archief 4: 385 (1858). - Type: 'L'île Bourbon', s.d., s. coll. s.n. (iso-: K000435612!).

\section{Short description}

Epiphytic; long-creeping filiform rhizomes, bearing sparsely distributed roots and long reddish brown trichomes, and widely separated fronds; fronds with wingless stipes, up to $4 \mathrm{~cm}$ long, slightly curled in the wild, flabellate to reniform, palmatisect with dichotomous venation; few sori, paratactic, bilabiate without a developed base and with toothed margins.

\section{Global distribution}

Western Indian Ocean, East and South Africa.

\section{Distribution in Comoros}

Anjouan, Grande Comore, Mohéli.

\section{Additional specimens examined}

COMOROS: AnJouAn, s. loc., 1905?, M.Lavanchie s.n. (P01430258, P00139617); Au camp de base du Mont N'Tringi, en montant vers la crête nord, 14 Nov. 2009, G. Viscardi et al. 166 (P02439808). Grande Comore, Massif du Karthala, 2 Dec. 2002, F.Rakotondrainibe et al. 6872 (P00312335). MohÉLI, Piste entre Miringoni et le Chalet St Antoine, 4 Nov. 2008, G.Rouhan et al. 888 (P02439806); Au-dessus de Drondroni, 27 Mar. 2011, E.Bidault et al. 65 (P02439771).

\section{Note}

The type of the species (J.B.G.M. Bory de St.-Vincent s.n.; BW20204010) is cited from Bourbon ('Habitat in insula Borboniae'; Bourbon is a former name for La Réunion) in the original description by Willdenow (1810) while the type specimen present at P would have been collected in 'Ile de France' (former name 
for Mauritius). Three distinct specimens are in fact on the same sheet: the first (P00612300) is thus from Ile de France (Mauritius) while the two others (P00612301 and P00065013) are from Bourbon (La Réunion). Without a precise reading of all the original notes on the sheet, it is easy to consider that all the specimens come from La Réunion. In the $19^{\text {th }}$ century, many plants collected in Mauritius were first transferred to Bourbon before being sent to Europe and this could explain potential confusion. On the sheet present at $\mathrm{P}$, it is clearly indicated that the Mauritian specimen has been sent to Willdenow who published in 1810 the name Trichomanes sibthorpioides. If the type corresponds well to the Berlin specimen, its real origin (La Réunion or Mauritius) remains ambiguous and questionable.

\section{Subgenus Sphaerocionium}

Subgenus Sphaerocionium is clearly distinct in the archipelago with two species characterized by lamina covered by a dense indumentum (see Fig. 2A). By contrast, all other Comorian Hymenophyllum species display glabrous lamina margins. Furthermore, the two Comorian Sphaerocionium species, Hymenophyllum hirsutum (L.) Sw. and $H$. capillare are easily distinguished from each other: $H$. capillare usually has wingless stipes and rachis (except in dwarf forms exhibiting winged rachis, at least in their upper part) while $H$. hirsutum always bears a developed wing all along the stipes and rachis. In addition, lamina hairs are pedunculated in H. hirsutum (see Fig. 2A) and not pedunculated in H. capillare.

\section{Hymenophyllum capillare Desv.}

Hymenophyllum capillare Desv., Mémoires de la Société linnéenne de Paris 6: 333 (1827). - Type: 'Pend aux arbres dans les forests humides Ile Bourbon', J.M.C. Richard 294 (holo-: P00065016!).

Hymenophyllum pendulum Bory in Bélanger, Voyage aux Indes Orientales. Botanique 2: 81, pl. 8, fig. 2 (1833). - Type: 'Ile de Mascareigne [La Réunion]', J.B.G.M. Bory de St.-Vincent s.n. (holo-: P00477830!).

Sphaerocionium pendulum (Bory) C.Presl, Eine botanische Abhandlung: 34 (1843).

Sphaerocionium capillare (Desv.) Copel., The Philippine Journal of Science 67 (1): 33 (1938).

\section{Short description}

Epiphytic; long-creeping filiform rhizomes, bearing sparsely distributed roots and long reddish brown trichomes, and widely separated pending fronds; fronds with usually wingless stipes and rachises (but rachises can be winged in dwarf forms, at least in its upper part), up to $40 \mathrm{~cm}$ long, linear to narrowly oblong, pinnate-pinnatifid, less often bipinnate, densely hairy with reddish brown, starred, non-pedunculated trichomes on stipes, rachises, veins and margins; numerous sori, paratactic, bilabiate without a developed base and with hairy margins.

\section{Global distribution}

Central Africa to the western Indian Ocean.

\section{Distribution in Comoros}

Anjouan, Grande Comore, Mayotte.

\section{Additional specimens examined}

COMOROS: s. loc., s.d., L.Humblot 288 (P01471899, P01471900, P01471901). AnJouAn, s. loc., 1875, J.M.Hildebrandt 1848(P00139602, P00139603); s. loc., 1886, L.Humblot 1545 (P00139601, P00327782, P01471898); Sommet du Tringi, 12 Nov. 2009, M.Pignal et al. 3727 (P02439800). Grande Comore, Massif du Karthala, 19 Nov. 2002, F.Rakotondrainibe et al. 6719 (P00311441), F.Rakotondrainibe et al. 6719bis (P00311442); Versant ouest du volcan Karthala, bois proche de Convalescence, 24 Oct. 2008, M.Pignal et al. 3386 (P02439787). MаYотTE, s. loc., s.d., L.Humblot s.n. (P00139600). 


\section{Note}

The sheet P00477830 is the only specimen upon which the validating diagnosis was based, and it was definitely designated by Bory as the type who mentioned on the sheet ' $\mathrm{N}$ ' for new; according to Art. 9.3 (McNeill et al. 2012) this specimen is thus established as the holotype of $H$. pendulum, rendering unnecessary the projected lectotypification by Pichi Sermolli (notula in Herb. P, September 1967) that was never published and thus is not effective.

In literature (e.g., Tardieu-Blot 1951, 2008), the range of fertile frond length for $H$. capillare varies from (6-)7 to $40 \mathrm{~cm}$ long. But in the wild, there are numerous specimens that display minute fertile fronds from 2.5 to $6 \mathrm{~cm}$ long, especially those well exposed while the largest and typical specimens usually occur in shadier places (pers. obs.). Such 'dwarf forms' are often lacking in collections and we decided here to integrate them in our Xper database as a distinct item.

\section{Hymenophyllum hirsutum (L.) Sw.}

Hymenophyllum hirsutum (L.) Sw., Journal für die Botanik 1800: 99 (1801). - Trichomanes hirsutum L., Species plantarum 2: 1098 (1753). - Type: based on Plumier (see Cremers \& Aupic 2008), 'Plum. fil. 73, t. 50, fig. B; Pet. fil. 105, t. 15, fig. 5. Habitat in America' (lecto-: Traité des fougères de l'Amérique (Plumier 1705), t. 50, fig. B, designated by Morton 1947); Plumier in herbier Tournefort 5315-1 (epi-: P-TRF P00322153!, designated by Cremers \& Aupic 2008).

Trichomanes ciliatum Sw., Nova genera \& species plantarum. Prodromus: 136 (1788). - Type: 'Habitat in Jamaica', O. Swartz S.n. (holo-: S; iso-: B-W 20222).

Hymenophyllum ciliatum (Sw.) Sw., Journal für die Botanik 1800: 100 (1801).

Hymenophyllum boryanum Willd., Species plantarum: 518, 519 (1810). - Type: 'Habitat in insula Borboniae' J.B.G.M. Bory de St.-Vincent s.n. (holo-: BW 20240010!; iso-: P00477832!). Note: The holotype specimen was considered by Roux (2009) as synonym of $H$. capillare, but it is clearly $H$. hirsutum, explaining why we consider here this species as synonym of the latter one; it is also the case of the $\mathrm{P}$ isotype but in the specimen noted $\mathrm{B}$, the second frond from the right belongs to $H$. capillare. Sphaerocionium ciliatum (Sw.) C.Presl, Eine botanische Abhandlung: 34 (1843).

Sphaerocionium hirsutum (L.) C.Presl, Eine botanische Abhandlung: 34 (1843).

Hymenophyllum ciliatum (Sw.) Sw. var. boryanum (Willd.) Mett. ex Kuhn, Filices Africanae: 39 (1868). Hymenophyllum ciliatum (Sw.) Sw. var. imbricatum Bonap., Notes ptéridologiques 14: 200 (1923) Type: Gabon, G. Le Testu 2160 (holo-: P00483495!; iso-: P00483494!).

Hymenophyllum ciliatum (Sw.) Sw. var. majus Tardieu, Flore de Madagascar et des Comores, $3^{e}$ famille Hymenophyllacées: 14 (1951). - Type: Madagascar, mont Tsaratanana, H.Perrier de la Bâthie 16451 (lectotype, here designated: hololecto-: P01315030!; isolecto-: P01315029!).

\section{Short description}

Epiphytic; long-creeping filiform rhizomes, bearing sparsely distributed roots and long reddish brown trichomes, and widely separated pending fronds; fronds with winged stipes and rachises, up to $13 \mathrm{~cm}$ long, lanceolate to triangular, pinnate-pinnatifid to bipinnate-pinnatifid, densely hairy with reddish brown, starred, pedunculated trichomes on stipes, rachises, veins and margins; numerous sori, paratactic, bilabiate without a developed base and with hairy margins.

\section{Global distribution}

Western Indian Ocean, tropical Africa, Neotropics.

\section{Distribution in Comoros}

Anjouan, Grande Comore, Mohéli. 


\section{Additional specimens examined}

COMOROS: AnJouAn, s. loc., 1886, L.Humblot 1545bis (P00139605); s. loc., 1905?, M.Lavanchie s.n. (P00139607); Sommet du Tringi, 12 Nov. 2009, M. Pignal et al. 3727bis (P02439801); Mjimandra, 1 Apr. 2011, E. Bidault et al. 111 (P02439774). Grande Comore, Nioumbadjou, 1911, L.Humblot s.n. (P00139606, P01314979); Base du Massif du Karthala, 10 Jun. 2006, J.-N.Labat et al. 3806 (P00527429); Versant ouest du volcan Karthala, bois proche de Convalescence, 24 Oct. 2008, M.Pignal et al. 3386bis (P02439788); Nfudo ya Mdrunda, au-dessus du village de Tsinimwapanga, 29 Nov. 2009, C.Loup et al. 545 (P02439777); En descendant du lieu dit Shihafuni vers le village de Tsinimwapanga, 29 Nov. 2009, C.Loup et al. 562 (P02439780). MoнÉLI, Chalet St Antoine, 5 Nov. 2008, M.Pignal et al. 3487 (P02439796); Au-dessus de Drondroni, 26 Mar. 2011, C.Loup et al. 601 (P02439784).

\section{Note}

The sheet P01315030 consists of many individuals with several fertile fronds, and specimens are representative of the morphology of the species. Contrary to the other sheet (P01315029), the label is provided with full collect details by the collector Perrier de la Bâthie, and it was definitely examined by Tardieu-Blot as evidenced by the handwritten annotation 'Hymenophyllum ciliatum var. majus Tardieu'. For all these reasons, P01315030 was selected as the lectotype specimen for the latter name.

\section{Subgenus Mecodium}

Subgenus Mecodium potentially groups five species in the area including eastern and southern Africa and the western Indian Ocean. These species are morphologically close and are thus often confused (Fig. 5): paleotropical populations of supposedly H. polyanthos (Sw.) Sw., East and South-African and Indian Ocean H. capense Schrad., East and South-African H. kuhnii C.Chr., the western Indian Ocean $H$. fumarioides Bory ex Willd. and H. inaequale (Poir.) Desv. In the fern flora of South Africa, Sim (1915) considered $H$. capense as a synonym of $H$. fumarioides, and $H$. inaequale is cited in the area but not H. kuhnii contrary to the other more recent local floras (e.g., Burrows 1990). Roux (2009) restricted H. fumarioides (the type is a mixed collect from Mauritius and La Réunion: J.B.G.M. Bory de St.Vincent 119, holotype BW20229010, isotype P00547028) and H. inaequale to the Indian Ocean and Tanzania, $H$. capense being treated as a distinct species with a wider distribution including the Indian Ocean, eastern Africa and South-Africa.

Our investigations allowed us to recognize and propose here only three species for subg. Mecodium in the archipelago as we will discuss here-after. These species are H. capense, H. inaequale and $H$. kuhnii.

\section{Hymenophyllum capense Schrad.}

Hymenophyllum capense Schrad., Göttingische gelehrte Anzeigen: 919 (1818). - Type: 'e Cap b. Sp.', s.d., M. Hesse s.n. (holo-: GOET008793!).

Hymenophyllum natalense Bosch, Nederlandsch Kruidkundig Archief 4: 386, 387 (1858). - Type: 'Port Natal', s. loc., s.d., W. Gueinzius s.n. (syn-: K, S-P-13305!); 'Klynrivier', s. loc., s.d., C.L.P. Zeyher 4642 (syn-: K000435627!); 'Gnadenthal', s. loc., s.d., J.C. Breutel s.n. (syn-: K, S-P-13307!).

Hymenophyllum zeyheri Bosch, Nederlandsch Kruidkundig Archief 4: 388 (1858). - Type: South Africa, s. loc., s.d., C.L.P. Zeyher s.n. (holo-: K).

Hymenophyllum tabulare Bosch, Nederlandsch Kruidkundig Archief 4: 397 (1858), nom. nov. for H. rarum Kunze (1847: 234), non R.Br. (1810: 159). - Type: 'Hab. Africa australis (Tafelberg, Duivelsberg, Hollandsberg)', C.F. Ecklon s.n. (syn-: K).

Mecodium capense (Schrad.) Pic.Serm., Webbia 27: 404 (1973).

Hymenophyllum thunbergii Eckl. ex C.Presl, Eine botanische Abhandlung: 32 (1843), nom. nud. - Type: 'e Cap b. Spei', M. Hesse s.n. (holo-: GOET). 


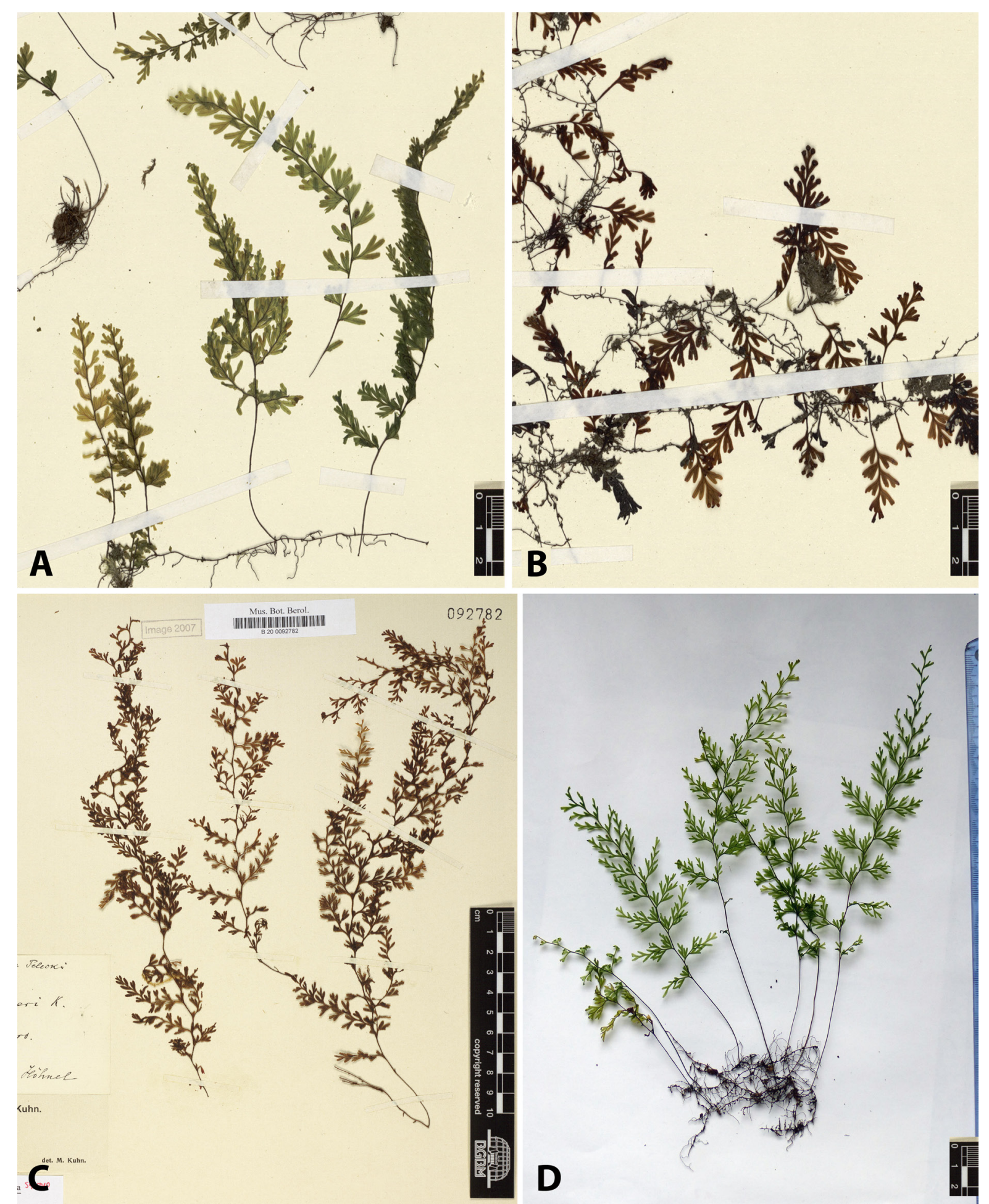

Fig. 5. Western Indian Ocean Hymenophyllum subg. Mecodium, illustrating morphological resemblance of taxa which are difficult to distinguish (see text). A. Hymenophyllum kuhnii C.Chr. from Comoros, firstly identified as H. polyanthos (Sw.) Sw. (F.Rakotondrainibe et al. 6864, P00312328). B. Hymenophyllum capense Schrad. from Madagascar, initially identified as H. fumarioides Bory ex Willd. (F.Rakotondrainibe et al. 6121, P00212664). C. Syntype of Hymenophyllum kuhnii C.Chr. from Tanzania (B200092782). D. Hymenophyllum inaequale (Poir.) Desv., representative specimen from La Réunion (L.Bauret 190, P). 


\section{Short description}

Epiphytic; long-creeping filiform rhizomes, bearing sparsely distributed roots and long reddish brown trichomes, and widely separated pending fronds; fronds with fully winged stipes and rachises, up to $15 \mathrm{~cm}$ long, more often less than $10 \mathrm{~cm}$ long, glabrous, linear to oblong, less often lanceolate, not more dissected than bipinnate, most often pinnatifid to pinnate-pinnatifid, with lamina apices usually obtuse to rounded, less often attenuate; pinnae often overlapping; few sori, paratactic, bilabiate without a developed base.

\section{Global distribution}

Comoros, Madagascar, Seychelles, Tanzania to South Africa.

\section{Distribution in Comoros}

Anjouan, Grande Comore.

\section{Additional specimens examined}

COMOROS: ANJOUAN, s. loc., 1886, L.Humblot 1567(P00139604, P01471280, P01471281, P01471282). Grande Comore, Kourani, 25 Nov. 2009, C.Loup et al. 536 (P02439776).

\section{Note}

All the specimens we examined here were first identified as $H$. fumarioides. However, a thorough study of $H$. fumarioides types reveals that the specimens collected by Bory de Saint-Vincent in Bourbon (La Réunion) and Ile de France (Mauritius) later sent to Willdenow who described the species, represent in fact H. tenellum (Jacq.) Kuhn, a clearly distinct taxon restricted to Mascarenes and Madagascar (see also Grangaud 2010) and belonging to subg. Hymenophyllum. Such synonymy had already been proposed by Badré (in Tardieu-Blot 2008). Consequently, Comorian H. fumarioides should therefore be treated as $H$. tenellum. However, except the type specimens from the Mascarenes which are clearly $H$. tenellum, all specimens identified as $H$. fumarioides collected in the western Indian Ocean including Comoros are clearly not $H$. tenellum and are actually not different from $H$. capense specimens, including type available at GOET herbarium and original description (Schrader 1818). Thus Comorian specimens widely identified as $H$. fumarioides should be treated as $H$. capense.

\section{Hymenophyllum inaequale (Poir.) Desv.}

Hymenophyllum inaequale (Poir.) Desv., Mémoires de la Société linnéenne de Paris 6 (2): 335 (1827). Trichomanes inaequale Poir., Encyclopedie méthodique, Botanique 8: 74 (1808). - Type: 'l'île de Madagascar', L.-M.A du Petit-Thouars s.n. (syn-: P00483501!, P00483502!).

Hymenophyllum gracile Bory ex Willd., Species plantarum: 527 (1810). - Type: 'Habitat in sylvis insulae Mauritii', J.B.G.M. Bory de St.-Vincent s.n. (holo-: BW20231010!; iso-: P00477835!).

Sphaerocionium gracile (Bory) C.Presl, Hymenophyllaceae. Eine botanische Abhandlung: 35 (1843). Mecodium inaequale (Desv.) Copel., The Philippine Journal of Science 67 (1): 96 (1938).

\section{Short description}

Epiphytic; long-creeping filiform rhizomes, bearing sparsely distributed roots and long reddish brown trichomes, and widely separated pending fronds; fronds stipitate, with stipes fully winged or winged only in their upper part and the wing usually thin (up to 2-3 cells wide), with rachises fully winged, up to $30(-40) \mathrm{cm}$ long, glabrous, quite variable in shape, triangular to (narrowly) lanceolate, never widely ovate, bipinnate-pinnatifid to tripinnate-pinnatifid, with lamina apices highly acute to attenuate, never obtuse or rounded; pinnae (especially the apical-most ones) usually not overlapping; numerous sori, paratactic, bilabiate without a developed base. 


\section{Global distribution}

Western Indian Ocean, Tanzania (where it could be confused with $H$. kuhnii).

\section{Distribution in Comoros}

Anjouan, Grande Comore.

\section{Additional specimens examined}

COMOROS: ANJouAn, s. loc., 1875, J.M.Hildebrandt 1849 (P00139613); s. loc., 1886, L.Humblot 1541 (P00139610, P01471284, P01471285, P01471286, P01471287); s. loc., Jul. 1940, R.Decary 16426 (P00139608); Sommet du Tringi, 12 Nov. 2009, M.Pignal et al. 3724 (P02439798). Grande Comore, s. loc., 1886, L.Humblot 1562 (P00139611), L.Humblot 1607 (P00139612).

\section{Note}

Hymenophyllum inaequale displays almost the same lamina division and shape variability as $H$. kuhnii (Fig. 5D; see the note concerning the latter species). However, phylogenetic molecular results indicate that $H$. inaequale is distinct from Tanzanian $H$. kuhnii and paleotropical $H$. 'polyanthos' (Hennequin et al. 2003, 2010). Typical $H$. inaequale specimens display lanceolate to narrowly lanceolate fronds with highly acute to attenuate apices (never obtuse or rounded), and pinnae or segments (especially the most apical ones) usually do not overlap. By contrast, many H. kuhnii specimens display ovate to widely ovate fronds with obtuse to rounded apices and mostly overlapping pinnae or segments, all these features supporting the distinctiveness from $H$. inaequale. However, many $H$. kuhnii specimens can also exhibit lanceolate to oblong fronds with attenuate apices and pinnae which do not always clearly overlap. Such equivocal or intermediate forms hinder a clear distinction between both species. Nevertheless, stipes of $H$. kuhnii are always fully winged with usually a wing of more than 3 cells wide (and observation of such wing usually requires a binocular). In typical $H$. inaequale, such wing is also observed, all along the stipe or only in its upper part, and it remains thin (up to 2-3 cells wide). Such subtle differences could allow distinguishing specimens exhibiting similar gross frond shape. But despite such subtle features, the morphological distinction between $H$. inaequale and $H$. kuhnii and/or all other non-neotropical $H$. 'polyanthos' remains difficult, especially in the wild (see Fig. 5).

\section{Hymenophyllum kuhnii C.Chr.}

Hymenophyllum kuhnii C.Chr., Index filicum: 363 (1905), nom. nov. for H. meyeri Kuhn (in Engler 1892: 94), non C.Presl (1843: 31, 50). - Type: As for H. meyeri Kuhn in Engler, Über die Hochgebirgsflora des tropischen Afrika: 94 (1892), nom. superfl., non C.Presl (1843: 31, 50), 'am Ruabach 1900-2300 m', H. Meyer 310 (lecto-: B200092787!; isolecto-: B200092783!, B200092784! designated by Beentje 2008); 'Kilimandscharo, im Urwald am Südabhang massenhaft von 1930-2800 m', R.F.X.R. von Höhnel 146 (syn-: B200092785), R.F.X.R. von Höhnel 147 (syn-: B200092782, B200092786!), O. Ehlers 66 (syn-: B200092790); 'im oberen Urwald um 2500 m, Aug. 1881', H. Meyer s.n. (syn-: not located); 'am Ruabach 1900-2300 m, Nov. 1889', H.Meyer s.n. (B200092788!).

Hymenophyllum henkelii Sim, South African Journal of Science 20: 309, pl. 9 (1923). - Type: Rhodesia, I.S. Henkel sub. F. Eyles 2559 (holo-: K0004356000!).

Mecodium kuhnii (C.Chr.) Copel., The Philippine Journal of Science 67 (1): 19 (1938).

Hymenophyllum polyanthos (Sw.) Sw. var. kuhnii (C.Chr.) Schelpe, Boletim da Sociedade Broteriana, sér. 2, 40: 156 (1966).

\section{Short description}

Epiphytic; long-creeping filiform rhizomes, bearing sparsely distributed roots and long reddish brown trichomes, and widely separated pending fronds; fronds stipitate, and stipes and rachises fully winged, 
with stipe wing usually well-developed ( $>3$ cells wide), up to $20 \mathrm{~cm}$ long (in Comoros), glabrous, quite variable in shape, lanceolate to oblong, sometimes widely ovate, pinnate-pinnatifid to bipinnatepinnatifid, with lamina apices attenuate to obtuse or rounded; pinnae often overlapping especially in widely ovate fronds; numerous sori, paratactic, bilabiate without a developed base.

\section{Global distribution}

Central Africa, East and South-Africa, Madagascar, Comoros, La Réunion?, Mauritius?

\section{Distribution in Comoros}

Grande Comore, Mohéli.

\section{Additional specimens examined}

COMOROS: Grande Comore, Changani, Forêt de Changani, 16 Nov. 1999, J.-N.Labat et al. 3146 (P00184014); La Convalescence, 24 Nov. 2002, F.Rakotondrainibe et al. 6791 (P00312067); Massif du Karthala (versant sud), 2 Dec. 2002, F.Rakotondrainibe et al. 6864 (P00312328); Hantsangoma, sur les pentes autour du lac, 19 Oct. 2008, G.Rouhan et al. 742 (P02439802); Massif de La Grille, bord de la piste menant au pylône, 9 Nov. 2008, M.Pignal et al. 3512 (P02433494); Nfudo ya Mdrunda, au-dessus du village de Tsinimwapanga, en chemin vers le second point de récolte, 29 Nov. 2009, C.Loup et al. 550 (P02439779). MohéLI, Piste entre Miringoni et le Chalet St Antoine, 4 Nov. 2008, G.Rouhan et al. 897 (P02439807).

\section{Note}

All the specimens we examined were most often identified as $H$. polyanthos. Hennequin et al. (2006) nevertheless demonstrated that paleotropical $H$. polyanthos populations are molecularly clearly distinct from neotropical $H$. polyanthos which might rather be restricted to the Neotropics (type from Jamaica). Specimens known as H. polyanthos in Comoros and Madagascar (in addition to some African specimens) do not significantly differ from African $H$. kuhnii (which was also considered as a variety of $H$. polyanthos by Schelpe in 1966), agreeing with the detailed treatment given by Kornaś (1993), and the identifications of Malagasy specimens as $H$. polyanthos var. kuhnii by F. Rakotondrainibe (e.g., F.Rakotondrainibe 2569 - P00059741, 1356 - P00064677, 2542 - P00046641). Hymenophyllum kuhnii initially considered as distributed from South Africa to Tanzania is quite variable in size, shape and frond division. The frond can reach $50 \mathrm{~cm}$ long and be pinnate-pinnatifid to bipinnate-pinnatifid, lanceolate to linear with short to long pinnae $(<6 \mathrm{~cm})$ and often oblong (especially after specimens at B, including the types; Fig. 5C). Hymenophyllum capense and specimens usually named $H$. polyanthos in the western Indian Ocean share the same gross morphology as continental H. kuhnii (see Fig. 5A-B). They would differ in the frond length, shape and division. Fronds of $H$. capense exceptionally exceed $15 \mathrm{~cm}$ long and are linear to oblong and usually not more than pinnate-pinnatifid (Fig. 5B) while most $H$. 'polyanthos' can reach $20 \mathrm{~cm}$ long with lamina lanceolate to ovate, less often oblong, pinnatepinnatifid to bipinnate-pinnatifid (Fig. 5A). Because of morphologically intermediate specimens for which identifications are necessarily uncertain (e.g., F.Rakotondrainibe 6791 - P00312067), we suspect that the three supposed distinct morpho-species could cover the whole high variability of a single taxon (here $H$. capense according to anteriority), according to lamina division and shape. We propose thus here to name $H$. kuhnii the Comorian specimens usually identified as $H$. polyanthos, a treatment that could also be applied to Malagasy specimens. Additional investigations including molecular data are requested to precise the specific status of these taxa (including $H$. capense). In absence of these studies, we nevertheless consider here $H$. capense as distinct, but not ruling out that such specimens could be dwarf forms of $H$. kuhnii (see Fig. 5A-C). If further additional studies confirm that $H$. capense specimens are dwarf forms of $H$. kuhnii, all populations identified as $H$. kuhnii should thus be named H. capense. 
Genus Polyphlebium Copel. (Copeland 1938)

This genus, here newly reported for the archipelago, is mostly neotropical with almost 15 species and a few ones in Asia, Australia, Pacific islands and a single species in tropical Africa and the western Indian Ocean. All species are epiphytic or lithophytic, small to large plants characterized by long-creeping, filiform rhizomes bearing pending simply-pinnate to highly divided fronds. The marginal sori have a cylindrical base and lips are more or less developed. Small to medium-sized taxa can be easily confused with Crepidomanes species by sharing the same growth-form and often the same gross frond shape and division. But all Polyphlebium species bear roots, even if few and reduced, while Crepidomanes species are all rootless or bear root-like shoots with caulinary anatomy (Schneider 2000), which are never observed in Polyphlebium. In addition, laminae never exhibit false veins or folds imitating veins, often observed in Crepidomanes.

\section{Polyphlebium borbonicum (Bosch) Ebihara \& Dubuisson}

Polyphlebium borbonicum (Bosch) Ebihara \& Dubuisson in Ebihara et al., Blumea 51: 240 (2006). Trichomanes borbonicum Bosch, Nederlandsch Kruidkundig Archief 5: 158, 159 (1861). - Type: 'Hab. Ins. Borboniae', L.H. Boivin 908 (lecto-: B200103881!, designated by Schelpe \& Anthony (1986: 76); isolecto-: P00065006!).

Trichomanes goetzei Hieron., Botanische Jahrbücher 28: 339 (1900). - Type: Tanzania, W. Goetze 194 (holo-: B200093147!; iso-: BM).

Vandenboschia borbonica (Bosch) G.Kunkel, Nova Hedwigia 6: 213 (1963).

Crepidomanes borbonicum (Bosch) J.P.Roux, Conspectus of southern African pteridophyta: 45 (2001).

\section{Short description}

Epiphytic or lithophytic; long-creeping filiform rhizomes, bearing sparsely distributed roots and reddish brown trichomes, and widely separated pending fronds; fronds stipitate, up to $17 \mathrm{~cm} \mathrm{long,} \mathrm{more} \mathrm{often}$ less than $10 \mathrm{~cm}$ long, deltoid to ovate, pinnate-pinnatifid to bipinnate-pinnatifid, without false veins or folds; sori numerous, paratactic, twice or more longer than wide, cylindrical with slightly dilated mouth.

\section{Global distribution}

Tropical Africa and the western Indian Ocean, or pantropical (see note).

\section{Distribution in Comoros}

Anjouan, Grande Comore.

\section{Additional specimens examined}

COMOROS: Anjouan, Sommet du Tringi, 12 Nov. 2009, M.Pignal et al. 3725 (P02439799). Grande Comore, La Convalescence (versant ouest du Massif), 24 Nov. 2002, F.Rakotondrainibe et al. 6793 (P00312024); Versant ouest du volcan Karthala, bois proche de Convalescence, 24 Oct. 2008, M. Pignal et al. 3383 (P02439786).

\section{Note}

This species, firstly considered restricted to tropical Africa and the western Indian Ocean, would be included into a large complex associating species from the Pacific and Neotropics (Ebihara et al. 2009). The species can be confused by its growth-form and gross frond shape and division with Crepidomanes bipunctatum and C. inopinatum. Both Crepidomanes species are rootless contrary to P. borbonicum but some Polyphlebium specimens can appear rootless if roots are not well developed. The sorus features are nevertheless more diagnostic. Sorus lips are clearly triangular in C. bipunctatum and not in 
P. borbonicum, and sori of $P$. borbonicum are twice or more longer than wide while sori of $C$. inopinatum are more or less as long as wide, always significantly less than twice longer (see Fig. 2C).

\section{Genus Trichomanes L. (Linnaeus 1753)}

As evidenced by Bauret et al. (2015), several paleotropical species formerly attributed to Trichomanes (the genus is mostly neotropical) are morphologically close to Abrodictyum spp. However, the single Comorian species T. boivinii Bosch is clearly distinct from Abrodictyum pseudorigidum occurring in the archipelago (see Fig. 4). The rhizomes of T. boivinii are short-creeping while those of Abrodictyum pseudorigidum are mostly suberect to erect. The main differences concern the ultimate segment shape. In T. boivinii, ultimate segments are multi-veined, ovate, spatulate and more or less toothed. In Abrodictyum pseudorigidum, ultimate segments are uni-veined, linear, and entire with tapered ends. Compared to Tardieu-Blot (1951) and Roux (2009), T. boivinii is new for the archipelago, although the species had already been reported by Kuhn (1868).

\section{Trichomanes boivinii Bosch}

Trichomanes boivinii Bosch, Nederlandsch Kruidkundig Archief 4: 373 (1858), as 'bovini'. - Type: 'Hab. Ins. Ste. Marie (Madagascar)', L.H. Boivin s.n. (Herb. de Franqueville, not located).

Trichomanes latipinnulata Bonap., Notes ptéridologiques 9: 28 (1920a) - Type: Madagascar, Mont Vatovavy, H.Perrier de la Bâthie 11549 (lecto-: P00466427!; isolecto-: P00466426!, here designated); Madagascar, H.Perrier de la Bâthie 7740 (syn-: P00466429!); Madagascar, Mont Vatovavy, H.Perrier de la Bâthie 11544 (syn-: P00466428!).

Trichomanes cornutum C.Chr., Notes ptéridologiques 12: 18, fig. 6 (1920). - Type: Madagascar, L. Humblot 280 (holo-: P00466432!; iso-: P00466430!, P00466431!). Note: Three herbarium sheets of this gathering are kept at $\mathrm{P}$, and although Christensen did not indicate the holotype in his publication, the holotype is established based on Art. 9.3 of the code (McNeill et al. 2012): the specimen P00466432 is indeed the only specimen examined by Christensen for his original description since he mentioned that any rhizome is unknown to him (the two other specimens P00466430 and P00466431 have rhizomes).

\section{Short description}

Terrestrial or lithophytic, often near streams; thick short-creeping rhizomes with robust roots and bearing clustered erect fronds; fronds well stipitate, up to $45 \mathrm{~cm}$ long, lanceolate to ovate, bipinnate to bipinnatepinnatifid, with multi-veined ovate to spatulate ultimate segments; numerous sori, paratactic, obconic to campanulate with a slightly dilated mouth.

\section{Global distribution}

Madagascar, Comoros.

\section{Distribution in Comoros}

Mayotte.

\section{Additional specimens examined}

COMOROS: Mayotte, Rivière Cambani, à $2.5 \mathrm{~km}$ à l'est de la ville de Combani, 12 Nov. 2002, F.Rakotondrainibe et al. 6675 (P00311390); Mtsangamouji, s.d. G.Viscardi 292 (P02439810).

\section{Note}

The sheet P00466427 consists of two complete individuals with fertile fronds, and specimens are representative of the morphology of the species. Moreover, this sheet was probably intended to be the 
holotype, as indicated by the handwritten annotation 'Original' by Bonaparte. For all these reasons, P00466427 was selected as the lectotype specimen for Trichomanes latipinnulata Bonap.

Genus Vandenboschia Copel. (Copeland 1938)

In tropical Africa and the western Indian Ocean, three potential morphologically close Vandenboschia species (the genus is pantropical with more than 15 species) are reported in literature and often confused especially in collection: V. speciosa (Willd.) G.Kunkel, $V$. radicans (Sw.) Copel. and V. gigantea (Bory ex Willd.) Pic.Serm. Vandenboschia speciosa is distributed in the wettest places in Europe and in Macaronesia. Molecular data clearly distinguished Neotropical $V$. radicans from European $V$. speciosa (Ebihara et al. 2007). According to Kornaś (1994), continental African populations belong to $V$. radicans, but have been often misidentified as $V$. speciosa in collections. Because of the lack of molecular data for continental African specimens and in absence of clear morphological diagnostic characters for discriminating those species, the specific status of continental African Vandenboschia populations remains nevertheless unknown and questionable. Vandenboschia gigantea is also molecularly a clearly distinct species (Dubuisson et al. 2013a, 2013b) a priori restricted to the western Indian Ocean. In absence of rhizomes, the highly-divided fronds with linear tapered ultimate segments of $V$. gigantea could be confused with those of many Abrodictyum spp., especially Abrodictyum pseudorigidum. But $V$. gigantea (as $V$. radicans and $V$. speciosa) is a climbing species with a quite long-creeping branched rhizome, while Abrodictyum pseudorigidum is terrestrial with a short monocaulous erect rhizome. As detailed by Dubuisson et al. (2003), V. gigantea grows on the ground forming large populations in the understory, with individuals able to secondary climb on tree-trunks. Many herbarium specimens are reported as epiphytes because they correspond to the climbing parts only. In such cases, rhizomes can appear rootless because the developed root system is mostly present on the terrestrial parts and on the rhizomes that begin to climb at the base of trunks, but this species in fact always bears roots. Roux (2009) also reports $V$. radicans for the archipelago but our investigations indicate that only $V$. gigantea is present in the region. Thus, all specimens from the area that have been identified as $V$. radicans (or Trichomanes radicans) refer actually to $V$. gigantea.

\section{Vandenboschia gigantea (Bory ex Willd.) Pic.Serm.}

Vandenboschia gigantea (Bory ex Willd.) Pic.Serm., Webbia 23: 197 (1968). - Trichomanes giganteum Bory ex Willd., Species plantarum: 514 (1810). - Type: 'Habitat in insula Borboniae', J.B.G.M. Bory de St.-Vincent s.n. envoyé à Willdenow sous le numéro 122 (holo-: BW20216!; iso-: P00477826!).

Trichomanes radicans Sw. var. gigantea (Bory ex Willd.) Mett. ex Kuhn, Filices Africanae: 36 (1868).

\section{Short description}

Terrestrial and climbing; long-creeping thick rhizomes with robust roots (especially on terrestrial parts), bearing widely separated erect to pending fronds; fronds stipitate, up to $60 \mathrm{~cm}$ long, lanceolate to ovate, bipinnate-pinnatifid to tripinnate-pinnatifid or more divided; numerous sori, paratactic, cylindrical to obconic with truncated mouth.

\section{Global distribution}

Comoros, Madagascar, La Réunion.

\section{Distribution in Comoros}

Anjouan, Grande Comore, Mohéli. 


\section{Additional specimens examined}

COMOROS: s. loc., s.d., L.Humblot 1576 (P01472915, P01472917); s. loc., s.d., L.H.Boivin s.n. (P01472922). AnJouan, s. loc., s.d., LH.Boivin s.n. (P01472925); s. loc., 1886, L.Humblot 1576 (P01472918); s. loc., 1905?, M.Lavanchie s.n. (P01604661). Grande Comore, s. loc., Nov. 1911, L.Humblot s.n. (P01472916, P01472919, P01472920, P01472921, P01472923); Versant ouest du volcan Karthala, bois proche de Convalescence, 24 Oct. 2008, M.Pignal et al. 3395 (P02439790); Versant ouest du volcan Karthala, bois proche de Convalescence, 24 Oct. 2008, M.Pignal et al. 3397 (P02439791); Versant ouest du volcan Karthala, bois proche de Convalescence, 24 Oct. 2008, M.Pignal et al. 3404 (P02433496); Kourani, 25 Nov. 2009, C.Loup et al. 529 (P02439775); Nfudo ya Mdrunda, au-dessus du village de Tsinimwapanga, en chemin vers le second point de récolte, 29 Nov. 2009, C.Loup et al. 546 (P02439778). MoHÉLI, Au-dessus de Drondroni, 26 Mar. 2011, C.Loup et al. 581 (P02439782).

\section{Dichotomous key for Comorian Hymenophyllaceae}

An Identification Assisted par Computer (CAI) is available via the Xper platforms (see p. 8). However, in the absence of network and computer facilities, a 'traditional' dichotomous key is useful. The present key requires that fertile specimens (with sori) are available. Didymoglossum cuspidatum is unknown in the archipelago; we nervertheless include it in the key because of the possible confusion with $D$. erosum.

1. Sori with a developed base, usually tubular 7

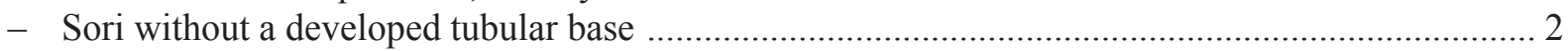

2. Fronds pinnate, never flabellate or reniform; sori margins entire …............................................. 3

- Fronds flabellate to reniform, palmatisect or digitate; sori margins toothed

Hymenophyllum sibthorpioides (Bory ex Willd.) Mett. ex Kuhn

3. Laminae hairy

- Laminae glabrous

4. Rachises and stipes winged; lamina hairs pedunculated Hymenophyllum hirsutum (L.) Sw.

- Rachises and stipes wingless (rachises winged in 'dwarf forms'); lamina hairs not pedunculated Hymenophyllum capillare Desv.

5. Lamina apices attenuate to obtuse or rounded; pinnae often overlapping 6

- Lamina apices highly acute to attenuate, never obtuse to rounded; pinnae usually not overlapping (especially the apical-most ones) Hymenophyllum inaequale (Poir.) Desv.

6. Fronds up to $10(-15) \mathrm{cm}$ long, and not more dissected than pinnate-pinnatifid

- Fronds up to 20(-25) cm long, pinnate-pinnatifid to bipinnate-pinnatifid

Hymenophyllum capense Schrad. Hymenophyllum kuhnii C.Chr.

7. Rhizomes thick and stout, $>1 \mathrm{~mm}$ diam., with numerous robust roots; fertile fronds up to $60 \mathrm{~cm}$ long

- Rhizomes filiform and more or less lax, $<1 \mathrm{~mm}$ diam., rootless or with root-like shoots covered with the same hairs as rhizomes, or with few reduced roots; fertile fronds usually up to $13 \mathrm{~cm}$ long ... 10

8. Rhizomes short-creeping or erect, never branched; fronds usually in clumps 9

- Rhizomes long-creeping, usually branched; widely separated fronds 
9. Rhizomes short-creeping; ultimate segments multi-veined, ovate to spatulate and usually toothed

Trichomanes boivinii Bosch

- Rhizomes erect; ultimate segments uni-veined, linear, not toothed, with a tapered end Abrodictyum pseudorigidum Bauret \& Dubuisson

10. Fronds not peltate

- Fronds peltate Didymoglossum hildebrandtii (Kuhn) Ebihara \& Dubuisson

11. Laminae with false veins (but not folds) parallel to true veins; ultimate segments if fronds not entire or lobed with more than one vein

- Laminae without false veins (or sometimes with folds) parallel to true veins; ultimate segments always univeined

12. Fronds with marginal hairs; sori with brown margins 13

- Fronds glabrous; sori without brown margins

13. Fronds entire, never lobed; a single sorus per fertile frond; marginal hairs stellate (with 3-4 rays) Didymoglossum lorencei (Tardieu) Ebihara \& Dubuisson

- Fronds entire to pinnatifid; often more than one sorus per fertile frond; marginal hairs isolated or cluster of $2-3(-6)$ hairs Didymoglossum robinsonii (Hook. ex Baker) Copel.

14. Fronds well stipitate, fertile fronds $1.5-9.0 \mathrm{~cm}$ long 16

- Fronds sessile or subsessile (sometimes stipitate); fertile fronds up to $1.3(-3.0) \mathrm{cm}$ long

15. Fronds entire, never lobed, sessile or subsessile; usually one single sorus per frond

Didymoglossum rotundifolium (Bonap.) J.P.Roux

- Fronds entire to lobed, subsessile to well stipitate; often more than one sorus per frond

Didymoglossum erosum (Willd.) J.P.Roux

16. Each sorus not located at the extremity of a long segment

- Each sorus mostly located at the extremity of a long segment

Didymoglossum kirkii (Hook.) Ebihara \& Dubuisson

17. Fertile fronds usually ovate to obovate or deltoid with mostly apical sori, rarely exceeding 6 per frond Didymoglossum cuspidatum (Willd.) Ebihara \& Dubuisson

- Fertile fronds usually lanceolate to oblong with mostly lateral sori, usually numerous, mostly exceeding 6 per frond Didymoglossum lenormandii (Bosch) Ebihara \& Dubuisson

18. Laminae without more or less continuous submarginal false veins; sori lips variable but never triangular.

- Laminae with more or less continuous submarginal false veins; sori lips triangular. Crepidomanes bipunctatum (Poir.) Copel.

19. Fertile fronds up to $3.5 \mathrm{~cm}$ long 20

- Fertile fronds 3.5-12.0 cm long (rarely longer) 21

20. Stipes winged, the wings broaden towards the apex

- Stipes wingless

Crepidomanes trinerve (Baker) Dubuisson \& Ebihara

Crepidomanes minutum (Blume) K.Iwats. var. mascarenensis Pynee \& Dubuisson 
21. Rhizomes rootless or bearing root-like shoots; sori more or less as long as wide, less than twice longer than wide Crepidomanes inopinatum (Pic.Serm.) J.P.Roux

- Roots, if any, few and reduced; sori longer than wide, often twice or more longer than wide Polyphlebium borbonicum (Bosch) Ebihara \& Dubuisson

\section{Discussion}

\section{Diversity of Comorian Hymenophyllaceae, distribution and collect effort}

Grande Comore is the largest island with the highest elevational gradient and potentially the highest diversity in terms of habitats. Therefore this island potentially could host more species than the three others. We show here that the most diversified island is Anjouan with 16 reported species while Grande Comore would host only 13 taxa.

These strong contrasts could be due to the contrasts in habitats but ecological data and preferences for every taxon (e.g., the type of forests and elevational range) are strongly lacking or parcellar and do not currently allow to precisely study relationships between species and habitat diversity. Precise habitat for each taxon must often be extracted from literature and observations on other localities, like Madagascar and Mascarenes. The lack of observation is also an impediment for establishing the altitudinal distribution for each species. Observations from neighbouring areas can be useful but some contrasts are possible. Some taxa usually found at a precise range of elevations in some areas can locally be observed at unexpected altitudes due to local, particular environmental conditions; this is the case for example for unexpected lowland Crepidomanes inopinatum in La Réunion (Dubuisson et al. 2014).

Strong contrasts can also be explained by disparity in collect effort. As shown in the Results section, Grande Comore, Mayotte and Mohéli have been actively prospected since 2008, whereas most of the known collects from Anjouan date back to the $19^{\text {th }}$ and $20^{\text {th }}$ centuries. This could explain that Anjouan with many old collects and specimens appear more diversified than Grande Comore (and the other islands) which has been more recently explored and thus could still reveal some more diversity. We also do not exclude that some species observed on an island more than 100 years ago (e.g., Anjouan) could currently be extinct because of the disappearance of their habitats, especially in areas where dense forests have been replaced by crops or urban zones. New investigations in the field are thus strongly needed to complete the data concerning Comorian Hymenophyllaceae, as it will be the case for other Comorian plants. In neighbouring areas (especially Madagascar and Mascarenes), there are several other filmy fern species that are often found sympatrically in equivalent habitats with species occurring in Comoros: Abrodictyum meifolium (Bory ex Willd.) Ebihara \& K.Iwats., A. tamarisciforme (Jacq.) Ebihara \& Dubuisson, Crepidomanes bonapartei (C.Chr.) J.P.Roux (often confused with C. minutum and C. trinerve; Dubuisson et al. 2013b), Didymoglossum cuspidatum, Hymenophyllum digitatum (Sw.) Fosberg, H. hygrometricum (Poir.) Desv., and H. tenellum. These taxa, so far unknown from the Comoros, can either be really absent in the archipelago, or not yet collected or observed. Expected additional field studies, complementary to investigations in collections, may as well result in the discovery of additional taxa as it could reveal species disappearance(s).

\section{Biogeographical hypotheses}

The inference of history and origins of taxa and communities in a locality requires a phylogenetic framework and molecular dating that are here missing. Some hypotheses can still be proposed by the study of the occurrence of Comorian taxa in neighbouring areas. Table 3 reports such occurrences in Madagascar, Mascarene archipelago, Seychelles, continental Africa and tropical Asia, in addition to the Neotropics. The most widespread species also present in Comoros are Hymenophyllum hirsutum distributed from the Neotropics to the western Indian Ocean, Polyphlebium borbonicum from the Neotropics to tropical Africa (via the Pacific islands and the western Indian Ocean) according to 
Table 3. List of Hymenophyllaceae species recorded for the Comoros archipelago and their occurrence in other areas. * According to Ebihara et al. (2009), P. borbonicum would be distributed from the Neotropics to tropical Africa (in addition to the Pacific islands and Australia). $\mathrm{X}=$ present or reported present.

\begin{tabular}{|c|c|c|c|c|c|c|}
\hline Taxa & Madagascar & Mascarenes & Seychelles & $\begin{array}{l}\text { Continental } \\
\text { Africa }\end{array}$ & Tropical Asia & Neotropics \\
\hline $\begin{array}{l}\text { Abrodictyum pseudorigidum } \\
\text { Bauret \& Dubuisson }\end{array}$ & $\mathrm{X}$ & & & $\mathrm{X}$ & & \\
\hline $\begin{array}{l}\text { Crepidomanes bipunctatum } \\
\text { (Poir.) Copel. }\end{array}$ & $\mathrm{X}$ & $\mathrm{X}$ & $\mathrm{X}$ & & $\mathrm{X}$ & \\
\hline $\begin{array}{l}\text { Crepidomanes inopinatum } \\
\text { (Pic.Serm.) J.P.Roux }\end{array}$ & $\mathrm{X}$ & $\mathrm{X}$ & & $\mathrm{X}$ & & \\
\hline $\begin{array}{l}\text { Crepidomanes minutum } \\
\text { (Blume) K.Iwats. }\end{array}$ & $\mathrm{X}$ & $\mathrm{X}$ & $\mathrm{x}$ & $\mathrm{X}$ & $\mathrm{X}$ & \\
\hline $\begin{array}{l}\text { Crepidomanes trinerve } \\
\text { (Baker) Dubuisson \& Ebihara }\end{array}$ & $\mathrm{X}$ & $\mathrm{X}$ & & & & \\
\hline $\begin{array}{l}\text { Didymoglossum erosum } \\
\text { (Willd.) J.P.Roux }\end{array}$ & $\mathrm{X}$ & & & $\mathrm{X}$ & & \\
\hline $\begin{array}{l}\text { Didymoglossum hildebrandtii } \\
\text { (Kuhn) Ebihara \& Dubuisson }\end{array}$ & $\mathrm{X}$ & & & & & \\
\hline \multicolumn{7}{|l|}{$\begin{array}{l}\text { Didymoglossum kirkii } \\
\text { (Hook.) Ebihara \& Dubuisson }\end{array}$} \\
\hline $\begin{array}{l}\text { Didymoglossum lenormandii } \\
\text { (Bosch) Ebihara \& Dubuisson }\end{array}$ & $\mathrm{X}$ & & & $\mathrm{X}$ & & \\
\hline $\begin{array}{l}\text { Didymoglossum lorencei } \\
\text { (Tardieu) Ebihara \& Dubuisson }\end{array}$ & $\mathrm{X}$ & $\mathrm{X}$ & & & & \\
\hline $\begin{array}{l}\text { Didymoglossum robinsonii } \\
\text { (Hook. ex Baker) Copel. }\end{array}$ & $\mathrm{X}$ & & & $\mathrm{X}$ & & \\
\hline $\begin{array}{l}\text { Didymoglossum rotundifolium } \\
\text { (Bonap.) J.P.Roux }\end{array}$ & $\mathrm{X}$ & & & & & \\
\hline Hymenophyllum capense Schrad. & $\mathrm{X}$ & & $\mathrm{X}$ & $\mathrm{X}$ & & \\
\hline Hymenophyllum capillare Desv. & $\mathrm{X}$ & $\mathrm{X}$ & & $\mathrm{X}$ & & \\
\hline $\begin{array}{l}\text { Hymenophyllum hirsutum } \\
\text { (L.) Sw. }\end{array}$ & $\mathrm{X}$ & $\mathrm{X}$ & $\mathrm{X}$ & $\mathrm{X}$ & & $\mathrm{X}$ \\
\hline $\begin{array}{l}\text { Hymenophyllum inaequale } \\
\text { (Poir.) Desv. }\end{array}$ & $\mathrm{X}$ & $\mathrm{X}$ & $\mathrm{X}$ & $\mathrm{X}$ & & \\
\hline Hymenophyllum kuhnii C.Chr. & $\mathrm{X}$ & & & $\mathrm{X}$ & & \\
\hline $\begin{array}{l}\text { Hymenophyllum sibthorpioides } \\
\text { (Bory ex Willd.) Mett. ex Kuhn }\end{array}$ & $\mathrm{X}$ & $\mathrm{X}$ & & $\mathrm{X}$ & & \\
\hline $\begin{array}{l}\text { Polyphlebium borbonicum } \\
\text { (Bosch) Ebihara \& Dubuisson }\end{array}$ & $\mathrm{X}$ & $\mathrm{X}$ & & $\mathrm{X}$ & $\mathrm{X}^{*}$ & $\mathrm{X}^{*}$ \\
\hline Trichomanes boivinii Bosch & $\mathrm{X}$ & & & & & \\
\hline $\begin{array}{l}\text { Vandenboschia gigantea } \\
\text { (Bory ex Willd.) Pic.Serm. }\end{array}$ & $\mathrm{x}$ & $\mathrm{X}$ & & & & \\
\hline
\end{tabular}

Ebihara et al. (2009), Crepidomanes minutum from continental Africa to the Pacific Ocean, followed by C. bipunctatum from the western Indian Ocean to the Pacific and $C$. inopinatum from central Africa to the western Indian Ocean. History of these taxa in the archipelago should require extended phylogenetic studies involving populations from various localities. Studies on Mascarenian Crepidomanes (Dubuisson et al. 2013b) suggested an Asiatic origin for the genus, then likely more than one dispersal event to the Afro-Malagasy region accounting for the diversity in the western Indian Ocean. The single endemic Hymenophyllaceae species, Didymoglossum kirkii, appears closely related (unpublished molecular data) to D. lenormandii also present in Madagascar and Tanzania. Apart from this species, all Comorian taxa are also present in Madagascar, three out of 19 are also present only in Madagascar and two are 
also present only in the western Indian Ocean (Madagascar, Mascarenes and/or Seychelles). The 11 species also present in continental Africa also occur in Madagascar. This could suggest that most of the Comorian Hymenophyllaceae could either originate from Madagascar or Africa, in accordance with the more or less equidistant localization of the archipelago between the African coast and Madagascar (see Fig. 1). That could be the case of all Hymenophyllum spp. Origin from Madagascar is nevertheless more probable for Trichomanes boivinii, Crepidomanes trinerve, Didymoglossum hildebrandtii, $D$. lenormandii, $D$. lorencei, $D$. rotundifolium, of course $D$. kirkii according to its proximity with D. lenormandii, and Vandenboschia gigantea. Fern spores are wind-dispersed, dispersals and then colonization of the Comoros could be facilitated by the major trade winds blowing from the south-east, thus from Madagascar.

\section{Prospective works}

In addition to a first revision of the diversity of the Hymenophyllaceae for the Comoros, our study allowed evidencing some taxonomic problems (especially concerning the complex $H$. capense/ fumarioides/kuhnii, plus $H$. inaequale) that need additional taxonomic investigations involving phylogenetic approaches at least at the western Indian Ocean and continental African scale, in addition to new investigations in the field as we developed here-above.

We also provide, with the Xper database, powerful tools for identification. This database built for Comorian Hymenophyllaceae could be a first step toward similar databases extended to or focused on neighbouring areas. This explains that some descriptors, such as ' 15 . Frond orientation' (see Appendix 1), which are not useful to discriminate Comorian taxa, can help identifying Abrodictyum meifolium present in Madagascar and Mascarenes. In addition, as discussed above, the presence of additional taxa in Comoros as A. meifolium is possible and such taxa could easily be added in the database. An Xper database is indeed easily updated and modified/adapted by adding (or deleting or correcting) new items (taxa) and descriptors and states.

\section{Acknowledgments}

This paper is dedicated to the memory of Professor Jean-Noël Labat (MNHN, Paris) who strongly contributed to developing French-Comorian collaboration in botanical research during the last two decades. This work mostly resulted from the Ahamada H. Saïd's international Master thesis that was supported by the program 'Sud Expert Plant' (SEP) funded by the French Ministry of Foreign Affairs, such international Masters program being also supported by 'Institut de Recherche pour le Développement' (IRD). SEP promoted research and training in botany in southern emerging countries. Most fieldwork in the Comoros was part of the program 'Connaître pour conserver: le patrimoine naturel caché des Comores' supported by the Fondation de la Recherche sur la Biodiversité (FRB). The authors would like to thank France Rakotondrainibe (MNHN, Paris) for fruitful discussions on filmy fern diversity and taxonomy in the western Indian Ocean area. They also thank Régine Vignes-Lebbe (Univ. P. \& M. Curie - UPMC, Paris), Frédéric Lison (UPMC, Paris), Florian Causse (UPMC, Paris) and Visotheary RivièreUng (CNRS, Paris) for their precious help with the Xper platform.

\section{References}

Adjanohoun E.J., Aké Assi L., Ali A., Eymé J., Guinko S., Kayounga A., Keyta A. \& Lebeas M. 1982. Médecine traditionnelle et pharmacopée. Contribution aux études ethnobotaniques et floristiques aux Comores. ACCT, Paris.

Agardh C.A., Holmberg L.P. \& Lundstrom P.M. 1825. Classes Plantarum. Literis Berlingianis, Lundae [Lund]. http://dx.doi.org/10.5962/bhl.title.7657 
Baker J.G. 1866. Description of six new species of simple fronded Hymenophyllaceae. Journal of the Linnean Society, Botany 9: 335-340.

Baker J.G. 1877. Flora of Mauritius and the Seychelles: a description of the flowering plants and ferns of those islands. Reeve, London.

Barthelat F. \& Boullet V. 2005. Index de la flore vasculaire de Mayotte - version 2005-1. In: Rolland R. \& Boullet V. (eds) Mayotte : biodiversité et évaluation patrimoniale. Contribution à la mise en cuvvre de l'inventaire Z.N.I.E.F.F: 103-197. Collectivité Départementale de Mayotte, DAF Mayotte \& Conservatoire Botanique National de Mascarin, Mayotte.

Barthelat F. \& Viscardi G. 2012. Flore menacée de l'île de Mayotte : importance patrimoniale et enjeux de conservation. Revue d'Ecologie. (La Terre et la Vie), supp. 11: 15-27.

Bauret L., Grall A., Senterre B., Rouhan G., Hennequin S., Ebihara A. \& Dubuisson J.-Y. 2015. New circumscription of Trichomanes cupressoides Desvaux (Hymenophyllaceae), an endemic filmy fern from Seychelles (Indian Ocean), and new insights into the genus Abrodictyum C.Presl in the western Indian Ocean. Phytotaxa 202: 1-14. http://dx.doi.org/10.11646/phytotaxa.202.1.1

Beentje H.J. 2008. Hymenophyllaceae. In: Beentje H.J. \& Ghazanfar S.A. (eds) Flora of Tropical East Africa. Published on behalf of the East African governments by Royal Botanic Gardens, Kew, England.

Bonaparte R. 1920a. Les Ptéridophytes de Madagascar. Première Partie. Trichomanes. Notes ptéridologiques, Fasc. 9: 13-33.

Bonaparte R. 1920b. Notes ptéridologiques, Fasc. 10. Edited and printed by the author, Paris.

Bonaparte R. 1921. Notes ptéridologiques, Fasc. 13. Edited and printed by the author, Paris.

Bonaparte R. 1923. Notes ptéridologiques, Fasc. 14. Edited and printed by the author, Paris.

Bonaparte R. 1925. Notes ptéridologiques, Fasc. 16. Edited and printed by the author, Paris.

Bory de Saint-Vincent J.B.G.G.M. 1829. Voyage autour du monde. Cryptogamie 6: 249-301.

Bory de Saint-Vincent J.B.G.G.M. 1833-1834. Cryptogamie. In: Bélanger C.P. (ed.) Voyage aux Indes Orientales. Botanique 2. Paris, France.

Boullet V. (ed.) 2011. Index de la flore vasculaire de Mayotte (Trachéophytes) : statuts, menaces et protections. - Version 2011.1 (mise à jour du 01 août 2011). Conservatoire botanique national de Mascarin, Antenne de Mayotte - Coconi, Mayotte. Available from http://floremaore.cbnm.org [accessed 24 Jan. 2017].

Brause G.G.W. 1915. Pteridophyta africana nova vel non satis cognita. Botanische Jahrbücher 53: 356433.

Brown R. 1810. Prodromus florae Novae-Hollandiae 1: [i]-viii, 145-590. Johnson, London.

Burrows J.E. 1990. Southern African ferns and fern allies. Frandsen Publisher, Sandton.

Christ H. 1901. Acotyledones vasculares. In: De Wildeman E. \& Durand T. (eds) Plantae Gilletianae Congolensis. Bulletin de l'Herbier Boissier, sér. 21 (9): 848-851.

Christensen C. 1905. Index filicum. Hagerup, Copenhagen.

Christensen C. 1920. New species of Hymenophyllaceae from Madagascar. In: Bonaparte R. (ed.) Notes ptéridologiques, Fasc. 12. Edited and printed by Bonaparte, Paris.

Copeland E.B. 1933. Trichomanes. The Philippine Journal of Science 51: 119-280.

Copeland E.B. 1938. Genera Hymenophyllacearum. The Philippine Journal of Science 67: 1-110. 
Cordemoy E. 1895. Flore de l'île de La Réunion. P. Klinsksieck, Paris.

Cremers G. \& Aupic C. 2008. Typifications dans l'herbier Tournefort pour des taxons représentés par des planches iconographiques de Plumier. Adansonia, sér. 3, 30: 17-30.

Cronquist A., Takhtajan A. \& Zimmermann W. 1966. On the higher taxa of Embryobionta. Taxon 15: 129-134. http://dx.doi.org/10.2307/1217531

Desvaux N.A. 1827. Prodrome de la famille des fougères. Mémoires de la Société linnéenne de Paris 6: $171-337$.

Dubuisson J.-Y. 1997. Systematic relationships within the genus Trichomanes sensu lato (Hymenophyllaceae, Filicopsida): Cladistic analysis based on anatomical and morphological data. Botanical Journal of the Linnean Society 123: 265-296. https://doi.org/10.1111/j.1095-8339.1997. tb01420.x

Dubuisson J.-Y., Hennequin S., Rakotondrainibe F. \& Schneider H. 2003. Ecological diversity and adaptive tendencies in the tropical fern Trichomanes L. (Hymenophyllaceae) with special reference to climbing and epiphytic habits. Botanical Journal of the Linnean Society 142: 41-63. https://doi. org/10.1046/j.1095-8339.2003.00165.x

Dubuisson J.-Y., Bary S., Ebihara A., Carnero-Diaz E., Boucheron-Dubuisson E. \& Hennequin S. 2013a. Epiphytism, anatomy and regressive evolution in trichomanoid filmy ferns (Hymenophyllaceae). Botanical Journal of the Linnean Society 173: 573-593. http://dx.doi.org/10.1111/boj.12106

Dubuisson J.-Y., Rouhan G., Grall A., Hennequin S., Senterre B., Pynee K. \& Ebihara A. 2013b. New insights into the systematics and evolution of the filmy fern genus Crepidomanes (Hymenophyllaceae) in the Mascarene Archipelago with a focus on dwarf species. Acta Botanica Gallica, Botany Letters 160: 173-194. http://dx.doi.org/10.1080/12538078.2013.819294

Dubuisson J.-Y., Hennequin S. \& Robert Y. 2014. Crepidomanes inopinatum var. tamonii (Hymenophyllaceae), a new lowland variety endemic to semi-dry forests in La Réunion. Phytotaxa 173: 163-167. http://dx.doi.org/10.11646/phytotaxa.173.2.7

Dubuisson J.-Y., Bauret L., Grall A., Li T., Ebihara A. \& Hennequin S. 2016. Discussion on the taxonomy of African fern Abrodictyum rigidum (Sw.) Ebihara \& Dubuisson and description of two new Abrodictyum C.Presl species (Hymenophyllaceae, Polypodiidae) for the Afro-Malagasy region. Phytotaxa 284: 151-168. http://doi.org/10.11646/phytotaxa.284.3.1

Dumont-d’Urville M.J. 1824. Flore des Malouines. Mémoires de la Société linnéenne de Paris 4: 573621.

Ebihara A., Dubuisson J.-Y., Iwatsuki K., Hennequin S. \& Ito M. 2006. A taxonomic revision of Hymenophyllaceae. Blumea 51: 221-280. http://dx.doi.org/10.3767/000651906x622210

Ebihara A., Iwatsuki K., Ito M., Hennequin S. \& Dubuisson J.-Y. 2007. A global molecular phylogeny of the fern genus Trichomanes (Hymenophyllaceae) with special reference to stem anatomy. Botanical Journal of the Linnean Society 155: 1-27. http://dx.doi.org/10.1111/j.1095-8339.2007.00684.x

Ebihara A., Nitta J.H., Lorence D. \& Dubuisson J.-Y. 2009. New records of Polyphlebium borbonicum, an African filmy fern, in the New World and Polynesia. American Fern Journal 99: 200-206. http:// dx.doi.org/10.1640/0002-8444-99.3.200

Emerick C.M. \& Duncan R.A. 1982. Age progressive volcanism in the Comoros Archipelago, Western Indian Ocean and implications for Somali plate tectonics. Earth and Planetary Science Letters 60: 415-428. https://doi.org/10.1016/0012-821x(82)90077-2

Engler A. 1892. Über die Hochgebirgsflora des tropischen Afrika. Koeltz, Koenigstein. 
Fournier E. 1873. Filices Novae-Caledoniae. Enumeratio monographica. Annales des Sciences naturelles, sér. 5, 18: 253-310.

Goddijn W.A. 1913. Synopsis Hymenophyllacearum. Mededeelingen van ’s Rijks-Herbarium 17: 1-36.

Grangaud E. 2010. Guide des Fougères et plantes alliées des Mascareignes. MNHN, Paris \& Biotope, Mèze.

Hennequin S. 2003. Phylogenetic relationships within the fern genus Hymenophyllum s.1. (Hymenophyllaceae, Filicopsida): contribution of morphology and cytology. Comptes Rendus Biologies 326: 599-611. https://doi.org/10.1016/s1631-0691(03)00146-x

Hennequin S., Ebihara A., Ito M., Iwatsuki K. \& Dubuisson J.-Y. 2003. Molecular systematics of the fern genus Hymenophyllum s.l. (Hymenophyllaceae) based on chloroplastic coding and noncoding regions. Molecular Phylogenetics and Evolution 27: 283-301. http://dx.doi.org/10.1016/S1055-7903(02)00404$\underline{9}$

Hennequin S., Ebihara A., Ito M., Iwatsuki K. \& Dubuisson J.-Y. 2006. New insights into the phylogeny of the genus Hymenophyllum s.l. (Hymenophyllaceae): revealing the polyphyly of Mecodium. Systematic Botany 31: 271-284. http://dx.doi.org/10.1600/0363644067775855775

Hennequin S., Ebihara A., Dubuisson J.-Y. \& Schneider H. 2010. Chromosome number evolution in Hymenophyllum (Hymenophyllaceae), with special reference to the subgenus Hymenophyllum. Molecular Phylogenetics and Evolution 55: 47-59. http://dx.doi.org/10.1016/j.ympev.2010.01.001

Hieronymus G.H.E.W. 1900. Filicales. In: Engler H.G.A. (ed.) Berichte über die botanischen Ergebnisse der Nyassa-See- und Kinga-Gebirgs-Expedition der Hermann- und Elise- geb. Heckmann-WentzelStiftung. III. Die von W. Goetze und Dr. Stuhlmann im Uluguru-gebirge, sowie die von W. Goetze in den Kisaki- und Khutu-Steppe und in Uhehe gesammelten Pflanzen. Botanische Jahrbücher 28: 339-350.

Hooker W.J. \& Greville R.K. 1831. Icones Filicum. Treuttel \& Wurtz, London.

Hooker W.J. \& Baker J.G. 1867. Synopsis filicum. Hardwicke, London.

Kornaś J. 1993. Filmy Ferns (Hymenophyllaceae) of Central Africa (Zaire, Rwanda, Burundi). 1. Hymenophyllum. Fragmenta Floristica et Geobotanica 38: 3-19.

Kornaś J. 1994. Filmy Ferns (Hymenophyllaceae) of Central Africa (Zaire, Rwanda, Burundi). 2. Trichomanes (excl. subgen. Microgonium). Fragmenta Floristica et Geobotanica 39: 33-75.

Kuhn F.A.M. 1868. Filices Africanae. Engelman, Leipzig.

Kuhn F.A.M. 1879. Cryptogamae vasculares. In: Ascherson F.P.A. (ed.) Von der Decken's Reisen in Ost-Afrika in 1851-1861. Botany 3: 1-91, 5 plates. Leipzig.

Kunkel G. 1963. The Hymenophyllales of Liberia (West Africa). Nova Hedwigia 6: 209-217.

Kunze G. 1836. Plantarum acotyledonearum Africae australis recensio nova. Linnaea 10: 480-570.

Kunze G. 1847. Die Farrnkräuter 1 (10): 223-252, [i]-vi, pls 91-100. Fleischer, Leipzig.

Labat J.-N., Pignal M., Rouhan G., Yahaya I., Andy A., Loup C. \& Bidault E. 2010. Le patrimoine naturel caché des Comores : passé, présent et avenir de la diversité des plantes vasculaires. Scripta Botanica Belgica 2: 1-46.

Leunis J. 1877. Synopsis der Pflanzenkunde. Band 3: Specielle Botanik, Kryptogamen, second edition. Hahn'sche Buchhandlung, Hannover.

Linnaeus C. 1753. Species plantarum Tomus II. Salvius, Stockholm. 
Lorence D.H. 1978. The pteridophytes of Mauritius (Indian Ocean): ecology and distribution. Botanical Journal of the Linnean Society 76: 207-247. https://doi.org/10.1111/j.1095-8339.1978.tb02362.x

McNeill J., Barrie F.R., Buck W.R., Demoulin V., Greuter D., Hawksworth L., Herendeen P.S., Knapp S., Marhold K., Prado J., Prud'Homme van Reine W.F., Smith F., Wiersema J.H. \& Turland N.J. 2012. International Code of Nomenclature for algae, fungi, and plants (Melbourne Code). Regnum Vegetabile 154. Koeltz Scientific Books, Koenigstein.

Morton C.V. 1947. The American species of Hymenophyllum, section Sphaerocionium. Contributions from the United States National Herbarium 29 (3): 139-201.

Moulaert N. 1998. Étude et conservation de la forêt de Mohéli (R.F.I. des Comores), massif menacé par la pression anthropique. $\mathrm{PhD}$ thesis, Faculté Universitaire des Sciences agronomiques de Gembloux, Belgium.

Myers N., Mittermeier R.A., Mittermeier C.G., Fonseca G.A.B. da \& Kent J. 2000. Biodiversity hotspots for conservation priorities. Nature 403: 853-858. https://doi.org/10.1038/35002501

Nougier J., Cantagrel J.M. \& Karche J.P. 1986. The Comores archipelago in the western Indian Ocean: volcanology, geochronology, and geodynamic setting. Journal of African Earth Sciences 5: 135-145. https://doi.org/10.1016/0899-5362(86)90003-5

Pascal O. 2002. Plantes et forêts de Mayotte. Patrimoines naturels 53, MNHN, Paris.

Peter A. 1929. Flora von Deutsch-Ostafrika. Feddes Repertorium. Beiheft 40: 1-98, Anhang: 1-9, t. I-V.

Pichi Sermolli R.E.G. 1968. Fragmenta pteridologiae I. Webbia 23: 159-207.

Pichi Sermolli R.E.G. 1973. Fragmenta pteridologiae III. Webbia 27: 389-460.

Pichi Sermolli R.E.G. 1982. Microgonium erosum and related species (Hymenophyllaceae) in continental Africa. Webbia 35: 241-260.

Pichi Sermolli R.E.G. 1983. A contribution to the knowledge of the Pteridophyta of Rwanda, Burundi and Kivu (Zaire). I. Bulletin du Jardin botanique national de Belgique 53, 1/2: 177-284. https://doi. org $/ 10.2307 / 3668036$

Plumier C. 1705. Traité des fougères de l'Amérique. Imprimerie royale, Paris.

Poiret J.L.M. 1808. Trichomanes. Encyclopedie méthodique, Botanique 8: 62-83.

Presl C.B. 1843. Hymenophyllaceae. Eine botanische Abhandlung. Haase, Prague.

Presl C.B. 1848. Die Gefässbündel im Stipes der Farrn. Abhandlungen der Königlichen Böhmischen Gesellschaft der Wissenschaften, ser. 5, 5: 307-356, t. 1-7.

Presl C.B. 1849 (1851). Epimeliae botanicae. Abhandlungen der Königlichen Böhmischen Gesellschaft der Wissenschaften, ser. 5, 6: 361-624, t. 1-15.

Pynee K., Hennequin S., Echternacht L. \& Dubuisson J.-Y. 2012. A new local variety of Crepidomanes minutum (Hymenophyllaceae) in the Mascarene Archipelago (Indian Ocean) and a new record for Mauritius. Phytotaxa 62: 25-30. http://dx.doi.org/10.11646/phytotaxa.62.1.5

Roux J.P. 2001. Conspectus of southern African pteridophyta. Southern African Botanical Diversity Network Report 13, SABONET, Pretoria.

Roux J.P. 2008. Pteridophytes. In: Figueiredo E. \& Smith G.F. (eds) Plants of Angola. Strelitzia 22: 210-216.

Roux J.P. 2009. Synopsis of the Lycopodiophyta and Pteridophyta of Africa, Madagascar and neighbouring islands. Strelitzia 23. 
Schelpe E.A.C.L.E. 1966. The Pteridophyta of Gogoronza Mountain, Southern Mozambique. Boletim da Sociedade Broteriana, sér. 2, 40: 149-179.

Schelpe E.A.C.L.E. \& Anthony N.C. 1986. Pteridophyta. In: Leistner O.A. (ed.) Flora of southern Africa: [i-iv], v-xv, 1-292. Department of Agriculture and Water Supply, Pretoria.

Schneider H. 2000. Morphology and anatomy of roots in the filmy fern tribe Trichomaneae H. Schneider (Hymenophyllaceae, Filicatae) and the evolution of rootless taxa. Botanical Journal of the Linnean Society 132: 29-46. http://dx.doi.org/10.1111/j.1095-8339.2000.tb01853.x

Schrader H.A. 1818. Göttingische gelehrte Anzeigen, unter der Aufsicht der Königl. Gesellschaft der Wissenschaften. Akademie der Wissenschaften in Göttingen, Göttingen.

Sim T.R. 1915. The ferns of South Africa. The University Press, Cambridge.

Sim T.R. 1923. Notes on South African and Rhodesian mosses. South African Journal of Science 20: 309-315.

Smith J.E. 1793. Tentamen botanicum de Filicum generibus dorsiferarum. Mémoires de l'Académie Royale des Sciences (Turin) 5: 401-422.

Stefanovic S., Rakotondrainibe F. \& Badré F. 1997. Sélaginellacées. Flore de Madagascar et des Comores 14. MNHN, Paris.

Swartz O. 1788. Cryptogamia. In: Nova genera \& species plantarum. Prodromus: 127-138. In Bibliopoliis Acad. M. Swederi, Stockholm. https://doi.org/10.5962/bhl.title.4400

Swartz O. 1801. Genera et species filicum ordine systematico redactarum. Journal für die Botanik 1800 (2): 1-136, t. 1, 2.

Tardieu-Blot M.-L. 1951. Hymenophyllacées. In: Humbert H. (ed.) Flore de Madagascar et des Comores, famille 3: 16-38. MNHN, Paris.

Tardieu-Blot M.-L. 1951-1971. In: Humbert H. (ed.) Flore de Madagascar et des Comores, Familles $1-13$ bis. MNHN, Paris.

Tardieu-Blot M.-L. 1960. Les Fougères des Mascareignes et des Seychelles. Notulae Systematicae 16: 151-201.

Tardieu-Blot M.-L. 1977. Sur quelques Hymenophyllaceae des Iles Mascareignes. Adansonia sér. 2, 17: $147-150$.

Tardieu-Blot M.-L. 2008. Hymenophyllacées. In: Autrey J.C., Bosser J. \& Ferguson I.K. (eds) Flore des Mascareignes, La Réunion, Maurice, Rodrigues: 71-90. IRD éditions, Paris. [posthumous publication, revised by F. Badré, MNHN, Paris].

Taton A. 1946. Révision des Hymenophyllacées du Congo Belge. Bulletin de la Société royale de Botanique de Belgique 78: 5-42.

Thiers B. 2016 [continuously updated]. Index herbariorum, a global directory of public herbaria and associated staff. Botanical Garden's Virtual Herbarium, New York. Available from http://sweetgum. nybg.org/science/ [accessed May 2016].

Ung V., Dubus G., Zaragüeta-Bagils R. \& Vignes-Lebbe R. 2010. Xper2: introducing e-taxonomy. Bioinformatics 26: 703-704. http://dx.doi.org/10.1093/bioinformatics/btp715

van den Bosch R.B. 1858. Synopsis Hymenophyllacearum, monographiae hujus ordinis prodromus. Nederlandsch Kruidkundig Archief 4: 341-419.

van den Bosch R.B. 1861. Hymenophyllaceas novas : cum ab aliis tum a semet ipso distinctas, ceu synopseos supplementum. Nederlandsch Kruidkundig Archief 5: 135-217. 
von Jacquin N.J. 1789. Collectanea Vol. III. Ex Officina Wappleriana, Vienna.

von Martius C.F.P. 1835. Conspectus regni vegetabilis. Schrag, Nürnberg.

Voeltskow A. 1917. Flora and Fauna der Komoren. Reise in Ostafrika in den Jahren 1902/05 3: 429-480.

Wessels Boer J.G. 1962. The new world species of Trichomanes sect. Didymoglossum and Microgonium. Acta Botanica Neerlandica 11: 277-330.

Willdenow C.L. 1810. Species plantarum. Nauk, Berlin.

Manuscript received: 3 February 2016

Manuscript accepted: 1 August 2016

Published on: 28 April 2017

Topic editor: Koen Martens

Desk editor: Laurence Bénichou and Connie Baak

Printed versions of all papers are also deposited in the libraries of the institutes that are members of the EJT consortium: Muséum national d'Histoire naturelle, Paris, France; Botanic Garden Meise, Belgium; Royal Museum for Central Africa, Tervuren, Belgium; Natural History Museum, London, United Kingdom; Royal Belgian Institute of Natural Sciences, Brussels, Belgium; Natural History Museum of Denmark, Copenhagen, Denmark; Naturalis Biodiversity Center, Leiden, the Netherlands. 


\section{Appendix 1}

\section{List of descriptors and states defined for the Xper database on Comorian Hymenophyllaceae}

\section{Habitat}

- 1. Ecology: \{1. Terrestrial; 2. Epiphytic; 3. Lithophytic; 4. Climbing\}

Terrestrial: Growing connected to the soil.

Epiphytic: Growing on another plant; i.e., the whole life cycle is performed fixed on another plant without connection to the soil and without parasitism. The host is named phorophyte.

Lithophytic: Growing on rocks or mineral substrate (constraints are often the same as the epiphytic habitat).

Climbing: Climbing vertically on a trunk or on another plant, usually by keeping a connection to the soil (climbing plants are usually first terrestrial).

\section{Rhizome and roots}

-2. Rhizome diameter: $\{1$. Thick $(\geq 1 \mathrm{~mm}) ; 2$. Filiform $(<1 \mathrm{~mm})\}$

If creeping, a thick rhizome is usually more or less rigid while a filiform rhizome appears mostly soft or lax. In Hymenophyllaceae all suberect to erect rhizomes are thick and rigid.

-3. Branching of rhizome: \{1. Always branched; 2 . Monocaulous or exceptionally branched\}

The rhizome is branched when it exhibits two or more connected axes. A single axis defines a monocaulous rhizome.

-4. Growth-form: \{1. Creeping or crawling rhizome (short or long); 2. Suberect to erect rhizome (and fronds are always in clumps)\}

The growth-form corresponds to the overall habit of the mature plant. It depends on the rhizome habit and growing, and on the frond disposition on the rhizome.

-5. (Growth-form) Inter-node length: $\{1$. Widely distanced fronds, inter-nodes $\geq 1 \mathrm{~cm} ; 2$. Closely distanced fronds, inter-nodes $<1 \mathrm{~cm}\}$-Conditions for inapplicability (suberect to erect rhizome (and fronds are always in clumps))

-6. Root system: $\{1$. Undeveloped roots or rootless (roots never present); 2. Few and/or not welldeveloped roots (but roots always present); 3 . Numerous robust well-developed roots\}

It defines the absence or presence, and density of the adventious root system. Polymorphism is possible especially in climbing Hymenophyllaceae when only terrestrial parts are rooted and the climbing 'epiphytic' ones are rootless. Coding can thus depend on the observed material (climbing or not parts).

- 7. Root-like shoots (Schneider 2000): \{1. Present; 2. Absent $\}$ - Conditions for inapplicability (Few and/or not well-developed roots (but roots always present), Numerous robust well-developed roots)

Caulinary (often) branched appendages that mimic true roots but clearly exhibit caulinary anatomy and are usually covered by the same hairs as on the rhizome. They were defined by Schneider (2000). Species with root-like shoots are also rootless.

-8. Hairs on (old/mature) rhizome: $\{1$. Always present; 2. Absent on mature rhizome (but can be present on young axes and apices)\}

Rhizome apices are always covered and protected by a dense indumentum. In many cases hairs are caducous but in the other cases they remain on old rhizomes. 
-9. Rhizome hair density: $\{1$. Scattered; 2. Dense $\}$ - Conditions for inapplicability (Absent on mature rhizome (but can be present on young axes and apices))

- 10. Rhizome hair length: $\{1$. Short $(\leq 1 \mathrm{~mm})$; 2. Long $(>1 \mathrm{~mm})\}$ - Conditions for inapplicability (Absent on mature rhizome (but can be present on young axes and apices))

Because of frequent polymorphism, this is applied to the longest hairs.

- 11. Rhizome hair branching: \{1. Simple; 2. Branched - Conditions for inapplicability (Absent on mature rhizome (but can be present on young axes and apices))

Hairs can be unicellular or (mostly) multicellular (and often articulated). They can be branched or not. Branched hairs are always multicellular.

- 12. Rhizome hair colour: \{1. Dark; 2. Reddish brown; 3. Whitish $\}$ - Conditions for inapplicability (Absent on mature rhizome (but can be present on young axes and apices))

\section{Whole frond}

- 13. Fertile (mature) frond length

The frond (the fern leaf) is composed of a stipe (or petiole) if present which extends to the rachis if present that bears the lamina. The lamina is the flattened part of the frond. The frond can be restricted to the lamina (without stipe) and the rachis could be not distinct. The measure is made from the insertion on the rhizome to the apex of the lamina. This includes the stipe length if present. The measure must be (if possible) made on the largest fertile mature frond. The unit of measurement is centimetre.

- 14. Frond proliferation: $\{1$. Presence of small scaly buds on the stipe able to provide a new leaf; 2 . Absence of small scaly buds on the stipe able to provide a new leaf

This defines the case where a new frond can originate from a bud directly on a stipe. It is a synapomorphy of Crepidomanes subg. Crepidomanes sect. Gonocormus. But in some populations belonging to this taxon, proliferation could not be observed.

- 15. Frond orientation: \{1. A single plane; 2. 3-D \}

Usually the whole frond is in a single plane. In some cases, pinnae and/or segments can be oriented in more than one plane. In such cases, the whole frond seems to occupy the three dimensions (3-D). In Abrodictyum meifolium from Madagascar, Seychelles and Mascarenes, such fronds have a 'swab' shape.

- 16. Crisped or curled fronds (in the wild): \{1. Absence; 2. Presence $\}$

This concerns only living and well-hydrated fronds as observed in the wild, because most species can curl after dehydration. Hymenophyllum tenellum from Mascarenes and Madagascar exhibits such crisped fronds in the wild.

\section{Stipe}

- 17. Stipe (or petiole): $\{1$. Present and well developed $(>1 \mathrm{~cm}) ; 2$. Few developed $(0.2-1 \mathrm{~cm})$ and/or frond subsessile; 3 . Sessile frond (can be peltate)\}

The part (if present) of the frond connecting the lamina to the rhizome. The stipe is usually extended by the rachis (i.e., the axis bearing the lamina).

- 18. Stipe section: \{1.Cylindrical;2. Canaliculate; 3. Elliptical-flattened $\}$-Conditions for inapplicability (Sessile frond (can be peltate))

- 19. Stipe diameter: $\{1$. Filiform $(\leq 1 \mathrm{~mm}) ; 2$. Thick $(>1 \mathrm{~mm})\}$-Conditions for inapplicability (Sessile frond (can be peltate)) 
-20. Hairs on the stipe: $\{1$. Present; 2. Absent $\}$ - Conditions for inapplicability (Sessile frond (can be peltate))

The stipe is glabrous or can bear hairs/trichomes, often at the margin of the wing if present. They are often (but not always) the same as on the rhizome.

-21. Hair distribution on the stipe: $\{1$. On the whole stipe; 2 . Only at the base of the stipe $\}$-Conditions for inapplicability (Absent)

-22. Stipe hair colour: \{1. Reddish brown; 2. Dark; 3. Whitish $\}$-Conditions for inapplicability (Absent)

-23. Stipe hair length: $\{1$. Short $(<1 \mathrm{~mm}) ; 2$. Long $(>1 \mathrm{~mm})\}$ - Conditions for inapplicability (Absent)

-24. Stipe hair branching: $\{1$. Simple; 2. Branched $\}$-Conditions for inapplicability (Absent)

-25 . Stipe hair density: $\{1$. Scattered; 2 . Dense $\}-$ Conditions for inapplicability (Absent)

-26. Stipe length - Conditions for inapplicability (Sessile frond (can be peltate))

The measure must be (if possible) made on the largest fertile mature frond. The unit of measurement is centimetre.

-27 . Wing on the stipe: $\{1$. Winged; 2 . Unwinged $\}$ - Conditions for inapplicability (Sessile frond (can be peltate))

Any flat surface along the petiole. But it could be confused with a decurrent base of an entire lamina.

-28 . Wing distribution along the stipe: $\{1$. Along the whole stipe; 2 . On the upper part of the stipe $\}$ - Conditions for inapplicability (Unwinged)

-29. Stipe wing margin: $\{1$. Entire; 2. Serrulate; 3. Undulate or crisped or sinuate $\}$ - Conditions for inapplicability (Unwinged)

-30 . Stipe wing width: $\{1$. Narrow (wing of $1-3$ rows of cells); 2 . Intermediate (wing with 4-6 rows of cells); 3 . Wide (wing with $>6$ rows of cells); 4 . Increasing width towards the stipe apex $\}$ - Conditions for inapplicability (Unwinged)

\section{Lamina}

-31. Overall lamina or frond (excluding stipe if present) shape: \{1. Linear; 2. Lanceolate; 3 . Flabellate; 4. Deltoid; 5. Triangular; 6. Oblong; 7. Circular (round); 8. Ovate; 9. Obovate; 10. Orbicular to reniform; 11. Elliptic\}

This overall shape does not take into account the lamina division.

-32. Apex shape: $\{1$. Rounded; 2 . Attenuated $\}$ - Conditions for inapplicability (Circular (round))

-33. Base shape: $\{1$. Rounded; 2. Decurrent; 3 . Obtuse; 4 . Truncated $\}$ - Conditions for inapplicability (Circular (round))

- 34. Peltate frond: $\{1$. Yes; 2. No $\}$ - Conditions for inapplicability (Linear, Lanceolate, Flabellate, Deltoid, Triangular, Oblong, Ovate, Obovate, Reniform)

The frond is connected on the rhizome at its lower surface near the centre instead of at its base.

-35. Degree of division of lamina: $\{1$. Entire with entire margin; 2. Entire with undulate margin; 3. Entire with toothed margin; 4. Lobed (or lobulate); 5. Pinnatifid; 6. Bipinnatifid; 7. Pinnate; 8. Pinnate-pinnatifid; 9. Bipinnate (2-pinnate); 10. 2-pinnate-pinnatifid; 11. 3-pinnate-pinnatifid or more divided; 12. Palmatisect or digitate $\}$

In ferns, the lamina can be entire or more often more or less deeply or highly divided. 
When the lamina is highly divided (usually more than once), the division is usually fractal.

When the division of the lamina does not exceed half the distance to the rachis, the lamina is lobed.

When the division provides distinct leaflets on an unwinged or short-winged rachis, each leaflet is named pinna and the lamina is once(1)-pinnate.

When the division exceeds half the distance to the rachis but a wide lamina remains along the rachis, the frond is pinnatifid.

If the frond is more than one-time divided, the second or more order division unit is the pinnule.

The segment is the ultimate division unit. It is thus the single division unit of a pinnatifid frond or the pinnule of a bi(2)-pinnate frond.

A frond which is n-time divided is thus n-pinnate or (n-1)-pinnate-pinnatifid or n-pinnatifid according to the depth of the division (see here above).

A lamina is palmatisect or digitate when all segments are almost connected close to the base.

-36. Rachis distinction: $\{1$. Not distinguishable; 2. Clearly distinct $\}$ - Conditions for inapplicability (Palmatisect or digitate)

The rachis (if present) extends the stipe (if present). It is the main axis of the lamina.

-37 . Wing on the rachis: $\{1$. Winged; 2. Unwinged; 3 . Unapplicable if lamina is entire to lobed $\}$ - Conditions for inapplicability (Not distinguishable)

Any flat surface along the rachis.

-38 . Wing distribution along the rachis: $\{1$. On the upper part of the rachis; 2 . Along the whole rachis $\}$ - Conditions for inapplicability (Unwinged, Unapplicable if lamina is entire to lobed)

-39. Rachis wing margin: \{1. Entire; 2. Serrulate; 3. Undulate or crisped or sinuate $\}$ - Conditions for inapplicability (Unwinged, Unapplicable if lamina is entire to lobed)

-40 . Rachis wing width: $\{1$. Narrow (wing with $1-3$ rows of cells); 2 . Intermediate (wing with 4-6 rows of cells); 3 . Wide (wing with $>6$ rows of cells) $\}$ - Conditions for inapplicability (Unwinged, Unapplicable if lamina is entire to lobed)

-41. Hairs on the rachis: $\{1$. Present; 2. Absent $\}$ - Conditions for inapplicability (Not distinguishable) The rachis is glabrous or can bear hairs/trichomes that are often (but not always) the same as on the stipe.

-42. Hair distribution along the rachis: $\{1$. On the entire rachis; 2. On the bottom half of the rachis $\}$ - Conditions for inapplicability (Absent)

- 43. Rachis hair density: \{1. Scattered; 2. Dense $\}$ - Conditions for inapplicability (Absent)

-44. Rachis hair length: $\{1$. Short $(\leq 1 \mathrm{~mm})$; 2. Long $(>1 \mathrm{~mm})\}-$ Conditions for inapplicability (Absent)

- 45. Rachis hair shape: $\{1$. Simple; 2. Stellate $\}$ - Conditions for inapplicability (Absent)

-46. Rachis hair colour: \{1. Dark; 2. Reddish brown; 3. Whitish $\}$ - Conditions for inapplicability (Absent)

-47. Insertion of pinnae on the rachis: $\{1$. Sessile (non-existent 'petiolule'); 2 . Stalked (with a distinct 'petiolule')\} - Conditions for inapplicability (Simple with entire margin, Simple with undulate margin, Lobed (or lobulate), Pinnatifid, Bipinnatifid, Palmatisect or digitate) 
Pinnae can have a 'petiolule' (i.e., the 'stipe' of pinnae) or be directly inserted on the rachis and are thus sessile.

-48 . Wing on the 'petiolule' ('stipe' of pinnae): $\{1$. Unwinged; 2 . Closely winged (wing with $1-3(5-6)$ rows of cells); 3 . Widely winged (wing with $>6$ rows of cells) $\}$ - Conditions for inapplicability (Sessile (non-existent 'petiolule'))

-49. Overlapping pinnae: \{1. Never to rarely; 2. Often to usually $\}$ - Conditions for inapplicability (Entire with entire margin, Entire with undulate margin, Entire with toothed margin, Lobed (or lobulate), Pinnatifid)

When adjacent pinnae overlap more or less (and not only at their base). The absence of overlapping is better observed in the wild or on fresh specimens because the pinnae can artificially overlap in some herbarium and dried specimens which have not been well prepared.

- 50. Pinna length - Conditions for inapplicability (Simple with entire margin, Simple with undulate margin, Lobed (or lobulate), Pinnatifid, Palmatisect or digitate)

From insertion on the rachis to the apex. The measure must be (if possible) made on the largest fertile mature frond and on the largest pinna (mostly among the basal-most ones). The unit of measurement is centimetre.

-51. Pinna width - Conditions for inapplicability (Simple with entire margin, Simple with undulate margin, Lobed (or lobulate), Pinnatifid, Palmatisect or digitate)

The measure must be (if possible) made on the largest fertile mature frond and on the largest pinna (mostly among the basal-most) and must correspond to the widest part of the pinna. The unit of measurement is centimetre.

- 52. Pinna phyllotaxis: $\{1$. Pinnae opposite or subopposite; 2 . Pinnae clearly alternate $\}$ - Conditions for inapplicability (Entire with entire margin, Entire with undulate margin, Lobed (or lobulate), Pinnatifid, Palmatisect or digitate)

Disposition pattern of pinnae along the rachis.

- 53. Overall pinna shape (excluding 'petiolule' if present): \{1. Lanceolate; 2. Deltoïd; 3. Oblong; 4. Ovate; 5. Obovate (often asymmetrical); 6. Linear; 7. Triangular\}-Conditions for inapplicability (Entire with entire margin, Entire with undulate margin, Lobed (or lobulate), Pinnatifid, Palmatisect or digitate)

As for lamina, this overall shape does not take into account the pinna division.

-54. Segment shape: \{1. Single-veined, linear with tapered ends, entire; 2. Single-veined, linear with rounded ends, entire; 3 . Single-veined, linear with rounded ends and toothed margin; 4. Multiveined, linear with rounded ends, entire or slightly lobed; 5 . Mostly multi-veined, ovate, spatulate, toothed $\}$ - Conditions for inapplicability (Entire with entire margin, Entire with undulate margin, Lobed (or lobulate))

The segment is the ultimate division unit of the lamina.

-55. Segment margin: \{1. Entire; 2. Serrulate or toothed; 3. Undulate or crisped or sinuate $\}$-Conditions for inapplicability (Entire with entire margin, Entire with undulate margin, Entire with toothed margin, Lobed (or lobulate))

- 56. Differentiated segment margin: $\{1$. Absence; 2 . Presence $\}$-Conditions for inapplicability (Entire with entire margin, Entire with undulate margin, Entire with toothed margin, Lobed (or lobulate))

This concerns the clear distinction in size and shape of marginal cells of ultimate segments by comparison with the other lamina cells. This does not include (sub)marginal false-veins (see 67). 
-57. Segment width: $\{1$. Narrow (segments with 1-3 rows of cells along the veins); 2 . Wide (> 6 rows of cells along the veins); 3 . Some or all ultimate segments without lamina or with lamina restricted to a single row of cells; 4 . Intermediate (4-6 rows of cells along the veins) $\}$ - Conditions for inapplicability (Entire with entire margin, Entire with undulate margin, Lobed (or lobulate))

-58 . Lamina length

The flattened part of the frond. The measure is made from the base of the lamina to its apex and by excluding stipe if present. The measure must be (if possible) made on the largest fertile mature frond. The unit of measurement is centimetre.

-59. Lamina width

The flattened part of the frond. The measure must be (if possible) made on the largest fertile mature frond and on the widest part. The unit of measurement is centimetre.

-60. Lamina venation: \{1. Dichotomous venation; 2. Flabellate venation; 3. Pinnate venation \}

This corresponds to the branching pattern of the veins, especially from the second order. In Hymenophyllaceae, the ultimate veins are indeed mostly dichotomous, thus the flabellate or pinnate patterns if present are observed only on the venation first orders. In highly divided fronds when pinnules or segments are uni-veined, the vein branching pattern is often confused with the pinnule/segment phyllotaxis.

-61 . Orientation of venation: \{1. Venation anadromous; 2. Venation catadromous\}

This corresponds to the orientation of the first vein of the second order (the veins of the first order originate directly from the rachis or from the base of the lamina if the rachis is not distinct, and are the first axis of the pinnae in divided fronds). In fronds which are more than once-pinnate, this also corresponds to the orientation of the first pinnule on every pinna.

When the first vein (or pinnule) is oriented towards the frond apex, the venation is anadromous.

When the first vein (or pinnule) is oriented towards the frond base, the venation is catadromous.

-62. Lamina thickness: \{1. One cell-thick; 2. More than one-cell thick\}

-63. Lamina texture: \{1. 'Translucent' and more or less delicate; 2. Coriaceous and more or less opaque\}

With a one-cell thick lamina, Hymenophyllaceae fronds are often translucent, diaphanous and appear fragile. But many species also exhibit firm or coriaceous lamina more or less opaque.

-64. Lamina cell orientation: $\{1$. Mostly more or less parallel to veins; 2 . Significantly not parallel to veins\}

- 65. Lamina indumentum (on margins): \{1. Presence of hairs on the margins; 2. Absence of hairs on the margins

Many Hymenophyllaceae display hairs/trichomes on their lamina margin. This explains the first generic name Trichomanes proposed by Linneus in Species plantarum (1753): Trichomanes means in ancient Greek 'hair of the head' and refers thus to such leaf indumentum.

- 66. Colour and type of lamina margin hairs: \{1. Dark, always single and isolated; 2. Dark, isolated or grouped by $2-3$ (up to 6 ), not pedunculated; 3 . Brown, single and isolated; 4 . Brown, starred, not pedunculated; 5. Brown, starred, pedunculated $\}$ - Conditions for inapplicability (Absence of hairs on the margins)

-67 . False veins or folds: $\{1$. Present; 2. Absent $\}$ 
Some Hymenophyllaceae display false veins that are cellular thickenings in the lamina without vascular elements. Some species also exhibit folds parallel to true veins that mimic false veins. These are thus not thickenings and are mostly observed in dried specimens.

-68 . Position of the false veins or folds: $\{1$. Continuous false marginal vein connected to true veins; 2 . False vein more or less continuous, parallel to the margin and not connected to true veins; 3 . False vein parallel to the true veins; 4. Folds simulating false veins parallel to the true veins; 5. False veins perpendicular to true veins $\}$ - Conditions for inapplicability (Absent)

\section{Sorus}

-69. Sorus position on the lamina and pinnae: \{1. Epitactic; 2. Paratactic; 3. 'Pantotactic'\}

In Hymenophyllaceae, sporangia born marginally on a receptacle that extends a terminal vein and such receptacle is protected by a terminal marginal indusium (lamina extension) defining the sorus (here an indusiate sorus).

When sori are located on terminal veins of lateral segments (rarely on the apical/terminal ones), they are paratactic.

When sori are always located on terminal veins of terminal segments in addition to lateral segments, they are epitactic.

When sori are located almost on all segments or terminal veins, they are pantotactic.

-70. Immersion of sorus in the lamina: $\{1$. Immersed (clearly immersed or isolated sorus with a welldeveloped wing); 2. Emerged, sometimes pedicellated (or with wing only at the base or a thin entire wing)\}

Sorus can be fully immerged in lamina and only the lips (if present) can emerge. Sorus (including base) can also fully emerge from the lamina. Intermediate states with lamina cells reaching more than half of the sorus sides is coded as 'immersed'.

-71 . Sorus density on the lamina: $\{1$. Few: from $(1-) 2$ to $5(-6)$ sori per fertile frond; 2 . Many: $>5-6$ sori per fertile mature frond; 3 . One single sorus per fertile frond, never more $\}$

-72. Sorus distribution on the lamina: $\{1$. At the upper part of the lamina; 2 . At the lower part of the lamina; 3. Almost on the whole lamina $\}$

This character is independent from the position (epitactic, paratactic, pantotactic). It corresponds to the distribution pattern on the whole lamina. But pantotactic sori are by definition distributed on the whole lamina.

- 73. Sorus receptacle shape: $\{1$. Globose or massive (and always included into the sorus); 2 . Cylindrical and filiform

The receptacle extends the terminal vein and is first enclosed within the sorus. It sequentially and basipetally produces and bears the sporangia. It can be short, more or less thick to globose, or filiform and often quite long (in this case it usually exserts outside the sorus). Mature sporangia are caducous and the youngest ones remain at the base of the receptacle.

-74. Sorus receptacle length (only for old and mature sori): \{1. Short: receptacle included into the sorus or slightly exserted; 2 . Long: receptacle clearly exserted outside the sorus mouth $\}$-Conditions for inapplicability (Globose or massive (and always included into the sorus))

If filiform, receptacle can exsert (or not) outside the sorus mouth. Mature sporangia are caducous and the youngest ones remain at the base of the receptacle. In species with long-exserted receptacle, the latter could not be visible if sori are still too young. 
-75. Sorus shape: $\{1$. Bilabiate sorus with a not well-developed base; 2 . Sorus with a well-developed base (often tubular) and with or without lips\}

In trichomanoids, the base of the sorus is usually tubular with or without a developed mouth with two lips.

In genus Hymenophyllum, the base is not or slightly developed (usually not tubular), the lips are well developed and thus the sorus is mostly clearly bilabiate, but there are a few exceptions (e.g., H. nephrophyllum Ebihara \& K.Iwats. = Cardiomanes reniforme (G.Forst.) C.Presl from Australia and New Zealand).

-76 . Sorus length/width ratio: $\{1$. More or less equal to (or less than) 1 but always $<2 ; 2$. Mostly $\geq 2$ (i.e. sorus always significantly longer than wide) $\}$

- 77. Sorus lips: \{1. Present (well developed); 2. Absent (truncated sorus) or quite slightly developed\} Lips, if present, are the outer edges at the opening of the indusium.

-78. Sorus lip shape: $\{1$. More or less rounded or ovate or elliptic (not clearly triangular); 2 . Triangular; 3. Obtriangular or more or less flabellate - Conditions for inapplicability (Absent (truncated sorus) or quite slightly developed)

-79. Opening of the sorus: $\{1$. More or less dilated mouth (not forming a well-developed collar); 2 . Mouth widely dilated as a collar; 3 . Lips usually parallel (more or less in the same plane) $\}$-Conditions for inapplicability (Absent (truncated sorus) or quite slightly developed)

- 80. Sorus lip margin: \{1. Entire brown margin; 2. Toothed or ciliate margin; 3 . Undifferentiated entire margin; 4. Entire margin bearing stellate hairs (often as on lamina margins) $\}$ - Conditions for inapplicability (Absent (truncated sorus) or quite slightly developed) 


\title{
Appendix 2
}

\section{List of additional examined specimens from non Comorian localities.}

\author{
Abrodictyum pseudorigidum Bauret \& Dubuisson
}

Malagasy specimens listed in Bauret et al. (2015) and Dubuisson et al. (2016).

Crepidomanes inopinatum (Pic.Serm.) J.P.Roux

MADAGASCAR: Eminiminy, Versant Est et sommet du Trafon'omby, 30 Oct. 1995, F.Rakotondrainibe 3005 (P00067100); Réserve Spéciale d'Ivohibe, à $8 \mathrm{~km}$ à l'est du village d'Ivohibe, 19 Oct. 1997, F.Rakotondrainibe 4173 (P00134194); Réserve Spéciale d'Ambohitantely, 9 Dec. 1997, F.Rakotondrainibe 4456 (P00134529); PN de Ranomafana, Forêt de Vatoharanana, 8 Oct. 2000, F.Rakotondrainibe 5931 (P00212410).

LA RÉUNION: 1832, J.N.Bréon s.n. (P01522393); May 1847, A.C.J.Bernier 907 (P01522402); 1892, H.J. de Cordemoy 133bis (P00477827); 1895, H.J. de Cordemoy s.n. (P01522401).

Crepidomanes minutum (Blume) K.Iwats. var. mascarenensis Pynee \& Dubuisson

Mascarenian specimens listed in Pynee et al. (2012).

Crepidomanes trinerve (Baker) Dubuisson \& Ebihara

MADAGASCAR: Parc national Montagne d'Ambre, 24 Jun. 1992, F.Rakotondrainibe 1725 (P00100238); Réserve spéciale d'Ambohitantely, 11 Dec. 1997, F.Rakotondrainibe 4495 (P00134573).

See also Mauritian specimens listed in Dubuisson et al. (2013b).

Didymoglossum hildebrandtii (Kuhn) Ebihara \& Dubuisson

MADAGASCAR: Nosy Mangabe, Piste reliant le camp Isidore au point culminant de l'île, sur le versant ouest, 2 Dec. 1993, F.Rakotondrainibe 1865 (P0006060).

Didymoglossum lorencei (Tardieu) Ebihara \& Dubuisson

MADAGASCAR: Massif du Manongarivo, Antsatrotro, versant NE à pente forte, 20 May 1992, F.Rakotondrainibe 1688 (P00100202); Nosy Mangabe, Toamasina, 2 Dec. 1993, F.Rakotondrainibe 1876 (P006071); Toamasina, Ambanizana, 5 Dec. 1993, F.Rakotondrainibe 1875 (P006070); Antsiranana, Andapa, Befingotra, 24 Oct. 1994, F.Rakotondrainibe 2171 (P00006382); Tolanaro, Réserve de l'Andohahela, 24 Oct. 1995, F.Rakotondrainibe 2931 (P01303568); Eminiminy, versant Est et sommet du Trafon'omby, 24 Oct. 1995, F.Rakotondrainibe 2907 (P00067003); Corridor reliant les réserves d'Andringitra et d'Ivohibe, 16 Jan. 1997, F.Rakotondrainibe 4387 (P00134469); Réserve Spéciale d'Ivohibe, 17 Oct. 1997, F.Rakotondrainibe 4166 (P00134185); Forêt de Vinanitelo, 28 Oct. 2000, F.Rakotondrainbe 6136 (P00212685); RNI n 4 Tsaratanana, Diego, Beangona, 26 Nov. 2000, A.Rasolohery 62 (P00338329); PN de Marojejy, 19 Oct. 2001, F.Rakotondrainibe 6299 (P00244844); PN de Marojejy, 27 Oct. 2001, F.Rakotondrainibe 6413 (P00244987); Daraina, Forêt de Binara, 8 Nov. 2001, F.Rakotondrainibe 6544 (P00248655); Forêt de Manatantely, 26 Nov. 2004, F.Rakotondrainibe 6972 (P00411791).

LA RÉUNION: Saint Philippe, Brûlé de Takamaka, 7 Jun. 2006, E.Grangaud 1752 (P01627307).

Didymoglossum robinsonii (Hook. ex Baker) Copel.

SOUTH AFRICA: Natal, Zululand, Ngoya forest, May 1916, J.R.Sim 2984 (P01627659).

Didymoglossum erosum (Willd.) J.P.Roux

MADAGASCAR: Réserve Spéciale du Manongarivo, Massif de Bekolosy, 13 Oct. 1991, F.Rakotondrainibe 1350 (P00064663); Forêt d'Andranomay, 20 Dec. 1996, F.Rakotondrainibe 3822 
(P00084696); Limite extérieure nord de la RS d'Ivohibe, 6 Oct. 1997, F.Rakotondrainibe 4002 (P00134003); Limite extérieure nord de la RS d'Ivohibe, 8 Oct. 1997, F.Rakotondrainibe 4058 (P00134066) Réserve Spéciale d'Ivohibe, 25 Oct. 1997, F.Rakotondrainibe 4239 (P00134271); Région de Tsinjoarivo, Forêt de Mahatsinjo, 7 Jan. 1999, F.Rakotondrainibe 4559 (P00134690).

Didymoglossum lenormandii (Bosch) Ebihara \& Dubuisson

MADAGASCAR: Montagnes à l'Est d'Ambo, Sep. 1908, H.Perrier de la Bâthie 7733 (P00466418, P00466417); Manankazo, Réserve spéciale d'Ambohitantely, 24 Jun. 1984, F.Rakotondrainibe 201 (P00064792); Eminiminy, 12 Nov. 1995, F.Rakotondrainibe 3096 (P00067201); Réserve Spéciale d'Ivohibe, 28 Oct. 1998, F.Rakotondrainibe 4266 (P00134299); PN de Ranomafana, Forêt de Vatoharanana, 5 Oct. 2000, F.Rakotondrainibe 5914 (P00212395); PN de Marojejy, 16 Oct. 2001, F.Rakotondrainibe 6260 (P00243910).

Didymoglossum rotundifolium (Bonap.) J.P.Roux

MADAGASCAR: Réserve Spéciale du Manongarivo, Massif d'Antsatrotro, 11 Oct. 1991, F.Rakotondrainibe 1348 (P00064690); Parc National de la Montagne d'Ambre, Lac Maudit, 28 Mar. 1992, F.Rakotondrainibe 1553 (P00085780); Forêt de Manatantely, 26 Nov. 2004, F.Rakotondrainibe 6971 (P00411792).

Hymenophyllum sibthorpioides (Bory ex Willd.) Mett. ex Kuhn

MADAGASCAR: Eminiminy, 25 Nov. 1995, F.Rakotondrainibe 3172 (P00067295); Eminiminy, 28 Nov. 1995, F.Rakotondrainibe 3205 (P00067329).

LA RÉUNION: s.d., M.Lepervanche 6(P00065013); s.d., J.B.G.M. Bory de St.-Vincent s.n. (P00612301); s.d., J.B.G.M. Bory de St.-Vincent s.n. (P00065012).

MAURITIUS: s.d., J.B.G.M. Bory de St.-Vincent s.n. (iso-: P00612300).

\section{Hymenophyllum capillare Desv.}

MADAGASCAR: Befingotra, RS d'Anjanaharibe-Sud, 18 Nov. 1994, F.Rakotondrainibe 2460 (P00046932); Daraina, Forêt de Binara, 6 Nov. 2001, F.Rakotondrainibe 6534 (P00248642).

LA RÉUNION: s.d., J.B.G.M.Bory de St-Vincent s.n. (P00477830).

Hymenophyllum hirsutum (L.) Sw.

MADAGASCAR: Réserve Spéciale de Manongarivo, 27 Sep. 2004, G.Rouhan et al. 270 (P00749199). LA RÉUNION: Forêt de Mare Longue, 23 Apr. 2002, J.Y.Dubuisson HR 2002-16 (P02433298).

\section{Hymenophyllum capense Schrad.}

MADAGASCAR: Iaraka Maroantsetra, 19 Aug. 1968, J.-L.Guillaumet 2080 (P01314347); RNI 12 du Marojejy, 14 Oct. 1996, F.Rakotondrainibe 3365 (P00084833); RNI 12 du Marojejy, 6 Nov. 1996, F.Rakotondrainibe 3637 (P00085205); RNI 12 du Marojejy, 9 Nov. 1996, F.Rakotondrainibe 3652 (P00085221); Réserve Spéciale d'Ivohibe, 26 Oct. 1997, F.Rakotondrainibe 4253 (P00134287); PN de Ranomafana, Forêt de Vatoharanana, 5 Oct. 2000, F.Rakotondrainibe 5898 (P00212381); Forêt de Vinanitelo, au pied de la montagne d'Ambodivohitra, 26 Oct. 2000, F.Rakotondrainibe 6121 (P00212664).

SOUTH-AFRICA: Natal, coll.? (P01314296), coll.? (P01314297).

Hymenophyllum inaequale (Poir.) Desv.

MADAGASCAR: Forêt d'Andrambovato, 14 Oct. 2000, F.Rakotondrainibe 6010 (P00212518).

MAURITIUS: Macabé, 5 Oct. 2010, S. Hennequin et al. 338 (P02432402). 


\section{Hymenophyllum kuhnii C.Chr.}

MADAGASCAR: s. loc., May 1850, L.H.Boivin s.n. (P00139614, P00139615); Parc national de la Montagne d'Ambre, Lac Maudit, 31 Mar. 1992, F.Rakotondrainibe 1544 (P00085772); Befingotra, 19 Nov. 1994, F.Rakotondrainibe 2476 (P00046942); Befingotra, 24 Nov. 1994, F.Rakotondrainibe 2509 (P00046976); Befingotra, 27 Nov. 1994, F.Rakotondrainibe 2542 (P00046641); Ambatomboay, RNI d'Andringitra, 15 May 1995, F.Rakotondrainibe 2637 (P00059817); Eminiminy, 28 Nov. 1995, F.Rakotondrainibe 3209 (P00067336); Massif d'Anjanaharibe, Forêt d'Analabe, 4 Nov. 1999, F.Rakotondrainibe 5142 (P00181123).

\section{Polyphlebium borbonicum (Bosch) Ebihara \& Dubuisson}

MADAGASCAR: Massif d'Antsatrotro, Réserve Spéciale du Manongarivo, 7 Oct. 1991, F.Rakotondrainibe 1367 (P00064688); Parc National de la Montagne d'Ambre, 23 Mar. 1992, F.Rakotondrainibe 1546 (P00085774); Parc National de la Montagne d'Ambre, Lac Maudit, 29 Mar. 1992, F.Rakotondrainibe 1545 (P00085773); Parc National de la Montagne d'Ambre, 19 Jul. 1992, F.Rakotondrainibe 1791 (P00100304); Ambatomboay, RNI d'Andringitra versant Est, 31 May 1995, F.Rakotondrainibe 2767bis (P00059992); Eminiminy, 24 Oct. 1995, F.Rakotondrainibe 2913 (P00067009); Eminiminy, 2 Nov. 1995, F.Rakotondrainibe 3029 (P00067125); Réserve Spéciale d'Ivohibe, 24 Oct. 1997, F.Rakotondrainibe 4186 (P00134207); Réserve Spéciale d'Ivohibe, 28 Oct. 1997, F.Rakotondrainibe 4265 (P00134298); Befingotra, 27 Nov. 1997, F.Rakotondrainibe 2537 (P00047000).

LA RÉUNION: s.d., Richard s.n. (P01330947); Bélouve, 2 Oct. 1882, s.c. s.n. (P01330933); Bébour, 26 Mar. 1969, T.Cadet 2099 (P01330937); Cirque de Takamaka, 4 Jan. 1972, T.Cadet 3395 (P01330939); Petite Plaine des Palmistes, 11 Jan. 1973, T.Cadet 4004 (P01330941).

\section{Trichomanes boivinii Bosch}

MADAGASCAR: Réserve Intégrale de Lokobe, 27 Jul. 1992, F.Rakotondrainibe 1788 (P00100302); Péninsule de Masoala, 20 Oct. 2004, G.Rouhan 326 (P00749272).

\section{Vandenboschia gigantea (Bory ex Willd.) Pic.Serm.}

MADAGASCAR: ; Massif du Manongarivo, 29 Sep. 2004, T.Janssen et al. 2417 (P00590653); Massif du Tsaratanana, 7 May 2005, T.Janssen 2858 (P00590910).

LA RÉUNION: Forêt de Mare Longue, 22 Apr. 2002, J.Y.Dubuisson HR 2002-14 (P02433296). 